\title{
Discovery of GPCR ligands for probing signal transduction pathways
}

\author{
Simone Brogi ${ }^{1,2}$, Andrea Tafi ${ }^{2}$, Laurent Désaubry ${ }^{3}$ and Canan G. Nebigil ${ }^{4}$ * \\ 1 European Research Centre for Drug Discovery and Development (NatSynDrugs), University of Siena, Siena, Italy \\ 2 Department of Biotechnology, Chemistry and Pharmacy, University of Siena, Siena, Italy \\ ${ }^{3}$ Therapeutic Innovation Laboratory, UMR7200, CNRS/University of Strasbourg, IIIkirch, France \\ ${ }^{4}$ Receptor Signaling and Therapeutic Innovations, GPCR and Cardiovascular and Metabolic Regulations, Biotechnology and Cell Signaling Laboratory, \\ UMR 7242, CNRS/University of Strasbourg - LabEx Medalis, Illkirch, France
}

\section{Edited by:}

Dominique Massotte, Institut des Neurosciences Cellulaires et Intégratives, France

\section{Reviewed by:}

Andrzej Pilc, Polish Academy of

Sciences, Poland

Sebastien Granier, Institut National de la Santé et de la Recherche Médicale, France

Helmut Schmidhammer, University of Innsbruck, Austria

\section{${ }^{*}$ Correspondence:}

Canan G. Nebigil, Receptor Signaling and Therapeutic Innovations, GPCR and Cardiovascular and Metabolic Regulations, Biotechnology and Cell Signaling Laboratory, UMR 7242, CNRS/University of Strasbourg LabEx Medalis, ESBS Pole API Boulevard Sébastien Brandt, BP 10413 Illkirch, France e-mail:nebigil@unistra.fr
G protein-coupled receptors (GPCRs) are seven integral transmembrane proteins that are the primary targets of almost $30 \%$ of approved drugs and continue to represent a major focus of pharmaceutical research. All of GPCR targeted medicines were discovered by classical medicinal chemistry approaches. After the first GPCR crystal structures were determined, the docking screens using these structures lead to discovery of more novel and potent ligands. There are over 360 pharmaceutically relevant GPCRs in the human genome and to date about only 30 of structures have been determined. For these reasons, computational techniques such as homology modeling and molecular dynamics simulations have proven their usefulness to explore the structure and function of GPCRs. Furthermore, structure-based drug design and in silico screening (High Throughput Docking) are still the most common computational procedures in GPCRs drug discovery. Moreover, ligand-based methods such as three-dimensional quantitative structure-selectivity relationships, are the ideal molecular modeling approaches to rationalize the activity of tested GPCR ligands and identify novel GPCR ligands. In this review, we discuss the most recent advances for the computational approaches to effectively guide selectivity and affinity of ligands. We also describe novel approaches in medicinal chemistry, such as the development of biased agonists, allosteric modulators, and bivalent ligands for class A GPCRs. Furthermore, we highlight some knockout mice models in discovering biased signaling selectivity.

Keywords: G protein-coupled receptors, GPCR, homology modeling, high throughput docking, biased agonists, biased signaling, allosteric modulators, bivalent ligands

\section{INTRODUCTION}

G protein-coupled receptors (GPCRs) use canonical (G proteinmediated) and non-canonical ( $G$ protein-independent, $\beta$-arrestin dependent) signaling pathways to assert their biological functions (Luttrell et al., 1999; Beaulieu et al., 2005; Lefkowitz and Shenoy, 2005; Abbas and Roth, 2008).

The ligands can bind to receptor either competitively (orthosterically) by interacting with the same receptor-binding site as the endogenous agonist or allosterically by exerting effects through a distinct binding site. Ligands binding at the orthosteric sites have been classified as agonists, antagonists, and/or inverse agonists based on their ability to mainly modulate $G$ protein signaling. The ligands can directly stabilize the "active" receptor conformations via a non-standard binding site (known as allosteric agonism) or modulate the binding of orthosteric ligands (known as allosteric modulation). Those ligands acting outside the orthosteric hormone binding sites can selectively engage subsets of signaling responses as "functional selectivity" or "ligand-biased signaling" (Khoury et al., 2014).

Several studies have shown that multivalent ligands, but not a monovalent ligands bind to the extracellular domains of receptors and trigger intracellular signaling by ligand-promoted receptor clustering (Sigalov, 2012). Ligands can be monovalent or bivalent, targeting specific GPCR dimers that may provide drugs with enhanced potency, selectivity, and therapeutic index. Biased ligands at GPCRs preferentially stimulate one intracellular signaling pathway over another (Violin et al., 2014). This functional selectivity of the ligands is extremely useful for elucidating the signal transduction pathways for both the therapeutic actions and the side effects of drugs. There is growing interest in developing biased GPCR ligands to yield safer, better tolerated, and more effective drugs.

Here, we discuss the discovery of GPCR ligands including biased agonists, allosteric modulators, and bivalent ligands and biased signaling selectivity for the class A GPCRs focusing on structure-based drug design (SBDD) and in silico screening (High Throughput Docking), medicinal chemistry, and genetic loss-of-function strategies.

\section{STRUCTURE-BASED DRUG DESIGN AND IN SILICO SCREENING (HIGH THROUGHPUT DOCKING) IN GPCRs DRUG DISCOVERY}

Computational methods represent invaluable tools in medicinal chemistry, including drug discovery step. Concerning the ligand discovery in GPCRs field, different techniques have been applied for selecting potential and selective chemical derivatives 
that bind to GPCRs (Andrews et al., 2014). Homology modeling and ligand screening, utilizing structure-, and/or ligand-based approaches represent the most common approaches to discover in silico novel ligands. Recently, fragment-based protocols have also been used. The impact of computational techniques in GPCR drug discovery has been relevant, due to the extreme difficulties for obtaining experimental high-resolution structural information on the active and inactive state of GPCRs. After the crystallization of the first mammalian GPCR (bovine rhodopsin; Palczewski etal., 2000; Figure 1), homology-modeling technique has been extensively adopted to predict structures and functions of different GPCRs and also to perform in silico screening.

In fact, sequence analysis suggested that family A GPCRs share the same arrangement, showing a high sequence similarity of the seven transmembrane helices, confirming the suitability of rhodopsin as a template (Li et al., 2010). During the last decade, we have seen a dramatic improvement in crystallization methods. Indeed, after about 7 years from the first solved structure of a mammalian GPCR, several three-dimensional structures have been published. The second crystallized GPCR was $\beta_{2}$-adrenergic receptor $\left(\beta_{2}\right.$ AR; Cherezov et al., 2007; Rasmussen et al., 2007) and then the $\beta_{1}$ AR (Warne et al., 2008). Subsequently, an exponential growth of crystallized GPCR structures in the protein data bank was observed. Actually, the three dimensional structures available of class A GPCRs comprise: the adenosine $\mathrm{A}_{2 \mathrm{~A}}$ receptor (Jaakola etal., 2008), the $\mathrm{D}_{3}$ dopamine receptor (Chien et al., 2010), the chemokine receptors CXCR1 (Park et al., 2012), CXCR4 (Wu etal., 2010), and CCR5 (Tan et al., 2013) the histamine $\mathrm{H}_{1}$ receptor (Shimamura et al., 2011), the sphingosine 1 phosphate receptor (Hanson etal., 2012), the $\mathrm{M}_{2}$ and $\mathrm{M}_{3}$ muscarinic receptors (Haga et al., 2012; Kruse et al., 2012), the $\mu, \mathrm{k}$, and $\delta$ opioid receptors (Manglik et al., 2012; Wu etal., 2012; Fenalti etal., 2014) as well as the nociceptin receptor (NOP; Thompson et al., 2012), bovine opsin receptors (Park etal., 2008; Scheerer et al., 2008), neurotensin receptor (White etal., 2012), the serotonin $5 \mathrm{HT}_{1 \mathrm{~B}}$ and $5 \mathrm{HT}_{2 \mathrm{~B}}$ receptors (Wacker et al., 2013; Wang et al., 2013a), protease-activated receptor 1 (PAR1; Zhang et al., 2012), the smoothened receptor (SMO; Wang et al., 2013b), and P2Y12 receptor (Zhang et al., 2014). Very recently, also a crystal structure of class B and C GPCRs such as glucagon receptor (Siu et al., 2013), corticotropin-releasing factor $1\left(\mathrm{CRF}_{1}\right)$ receptor (Hollenstein et al., 2013) and metabotropic glutamate receptor 5 (Dore et al., 2014) respectively, have been reported.

These achievements are largely attributable to the application of high-throughput methods for lipidic cubic phase (LCP) crystallography (Cherezov et al., 2004) and protein engineering with the generation of GPCR-T4 lysozyme (Rosenbaum et al., 2007) and GPCR-BRIL fusion proteins (Chun et al., 2012). Thermo stabilization (Serrano-Vega et al., 2008) methods represent another useful tool appropriate to GPCRs crystallization. Notably, these techniques can be generally applicable to structurally diverse GPCRs. Moreover, a relevant number of receptors have been solved with both bound antagonists and agonists.

The availability of numerous different GPCR templates offers diverse options in GPCR modeling. In particular, the application of multiple templates to the homology modeling protocols has been demonstrated to improve the reliability of the computational models including GPCRs (Fernandez-Fuentes et al., 2007; Mobarec etal., 2009; Sokkar et al., 2011; Cappelli et al., 2013; Gemma et al., 2014b).

In conclusion, the availability of a relevant number of crystal structures improves results of homology modeling procedures by using novel methodology such as multiple-templates based alignment for building the structure of GPCRs as well as the three-dimensional structure of any type of proteins (Cappelli et al., 2013; Gemma et al., 2014a; Giovani et al., 2014). Moreover, the
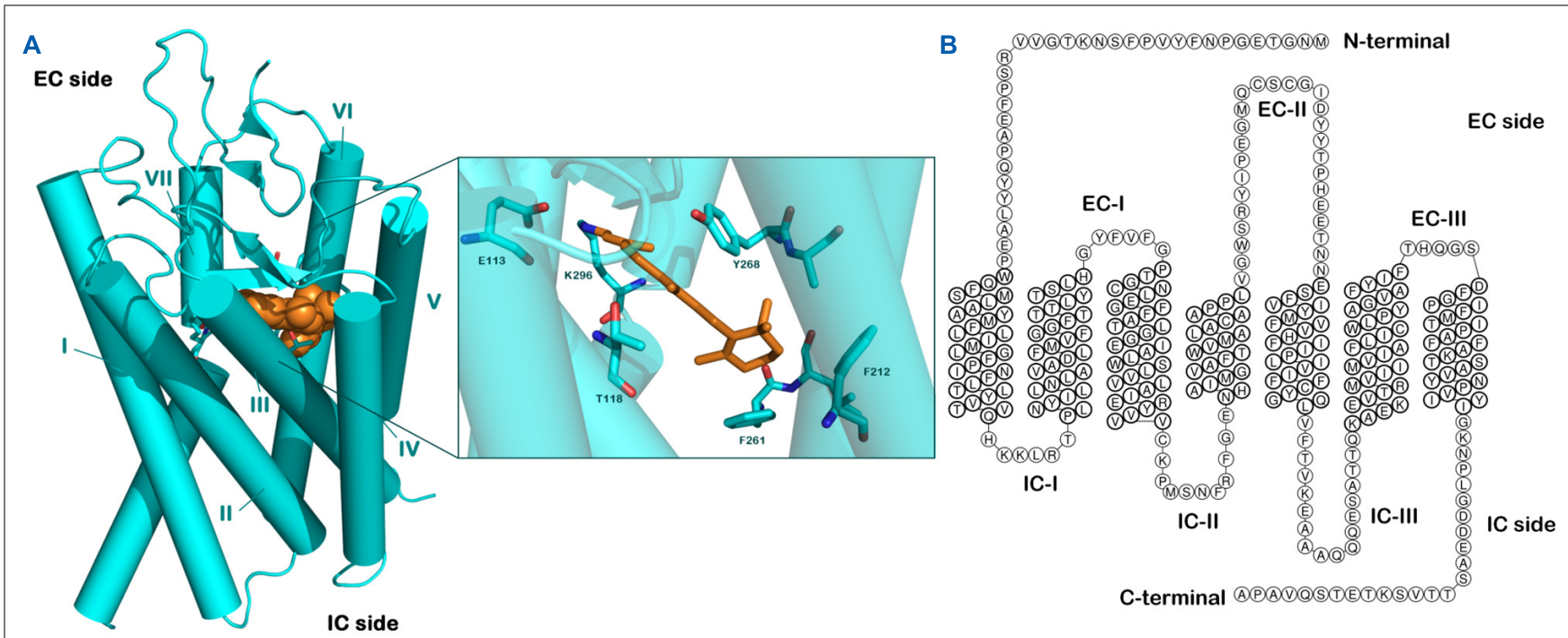

FIGURE 1 | Structure of rhodopsin. (A) Crystal structure of bovine rhodopsin covalently linked with retinal adapted from PDB file 1F88. (B) Snake-like diagram for the bovine rhodopsin highlighting extracellular (EC) and intracellular (IC) loops. 
accessibility of GPCR crystal structures unlocked opportunities to use alternative methods for GPCR drug discovery, mainly SBDD. SBDD approaches are extensively used in drug discovery of novel compounds based on three dimensional protein structures using various computational methods. The impact of GPCR crystal structures on SBDD has been instantaneous and has led to the discovery of novel ligands for different GPCRs (Kooistra et al., 2013). Furthermore, as above mentioned the increase of GPCR determined structures assures a large number of potential available templates, guaranteeing an improvement of quality of GPCR homology models for virtual screening. Indeed, virtual screening has become a routine tool for selecting putative lead compounds and identifying potential drug candidates for a given target (Brogi et al., 2009, 2011, 2013; Castelli et al., 2012). Although ligand-based methods were found to be useful for structurally non-characterized targets, high throughput docking is clearly the most popular approach used in receptor based virtual screening using both experimental and theoretical sources (Abagyan and Totrov, 2001). In this review, we will present an overview of the most relevant structure-based approaches for identifying novel ligands, targeting allosteric, and/or orthosteric binding sites, for some of the class A GPCRs.

\section{DRUG DESIGN AND DISCOVERY IN CARDIOVASCULAR DISEASES $\beta$-adrenergic receptors}

The selectivity of compounds for $\beta_{1}$ - and $\beta_{2}$-(AR) is an important issue to take into account in current adrenoreceptor drug design. A structure-based design approach using protein-ligand crystal structures of the $\beta_{1} A R$ is the first example of GPCR crystallography with ligands derived from fragment screening. In fact, the structures of the stabilized $\beta_{1} \mathrm{AR}$ in complex with two ligands were determined at resolutions of 2.8 and $2.7 \AA$, respectively (Christopher et al., 2013). A very elegant work has been recently carried out by Christopher et al. (2013) using biophysical fragment screening of a thermostabilized $\beta_{1} \mathrm{AR}$. They also applied surface plasmon resonance (SPR) to identify moderate affinity, high ligand efficiency (LE) arylpiperazine hits. Subsequent hit to lead follow-up confirmed the activity of the chemotype. Vilar etal. (2010) evaluated the applicability of ligand-based and structure-based models to quantitative affinity predictions and virtual screening for ligands of the $\beta_{2} \mathrm{AR}$.

The crystal structure of $\beta_{2}$ AR has been used by Kolb et al. (2009) to investigate the advantages and limitations of the structure-based approach in ligand discovery. The authors docked about 1,000,000 commercially available compounds against the $\beta_{2} \mathrm{AR}$ structure. Twenty five hits have been selected and submitted to biological evaluation. Six compounds were active with binding affinities $<4 \mu \mathrm{M}$, with the best molecule that showed a Ki of $9 \mathrm{nM}$. Moreover, five of these molecules have been found as inverse agonists (Kolb et al., 2009).

Sabio etal. (2008) and Topiol and Sabio (2008) performed a high-throughput docking with proprietary and commercial databases to investigate the usefulness of crystal structure for discovery of novel chemical classes acting as $\beta_{2} \mathrm{AR}$ inhibitors. These findings were further validated using $\mathrm{X}$-ray structures of $\beta_{2}$ AR/Timolol (Hanson et al., 2008), via in silico high-throughput docking of proprietary and commercial databases. This study resulted in the identification of ligands with relevant affinity for $\beta_{2}$ AR (Sabio et al., 2008; Topiol and Sabio, 2008).

More recently, Weiss et al. (2013) reported a prospective, large library virtual screen of 3.4 million molecules, yielding four full agonists and two partial agonists. The exploration of features that confer selectivity to the designed compounds has also been investigated by Xing et al. (2009). The authors developed a selective pharmacophore model based on a series of selective $\beta_{2} \mathrm{AR}$ agonists, presenting the first study using a ligand-based computational approach to generate specific three-dimensional pharmacophore hypotheses for the $\beta_{2} \mathrm{AR}$ from its selective agonists. The best pharmacophore hypothesis consisted of five chemical features (one hydrogen-bond acceptor, one hydrogen-bond donor, two ring aromatic, and one positive ionizable feature). The result was in accordance with the reported interactions between the $\beta_{2} \mathrm{AR}$ and agonists. Interestingly, the pharmacophore hypothesis can perfectly differentiate $\beta_{2}$-agonists from $\beta_{1}$-agonists, providing a valuable tool for virtual screening to find selective compounds against $\beta_{2} \mathrm{AR}$.

\section{Endothelin receptors}

In mammals, endothelins (ETs) are potent regulators of vessel functions involved in the pathophysiology of cancer, congestive heart failure, cardiovascular, proteinuria, and glomerulosclerosis. These peptides $\left(\mathrm{ET}_{1-3}\right)$ exert their biological effects via activation of four ET receptors, $\mathrm{ET}_{\mathrm{A}}, \mathrm{ET}_{\mathrm{B} 1}, \mathrm{ET}_{\mathrm{B} 2}$, and $\mathrm{ET}_{\mathrm{C}}$. Activation of the $\mathrm{ET}_{\mathrm{A}}$ receptor is associated with pronounced vasoconstriction whereas $\mathrm{ET}_{\mathrm{B}}$ receptor occupation is linked to vasodilation. In addition, other subtypes of the $\mathrm{ET}_{\mathrm{B}}$ receptor exist, one mediating vasodilation $\left(\mathrm{ET}_{\mathrm{B} 1}\right)$ and the other eliciting constriction $\left(\mathrm{ET}_{\mathrm{B} 2}\right)$. An additional receptor subtype, $\mathrm{ET}_{\mathrm{C}}$, has been identified although its physiological significance is uncertain (Pollock et al., 1995)

Funk etal. (2004) applied a pharmacophore model of endothelin- $\mathrm{A}\left(\mathrm{ET}_{\mathrm{A}}\right)$ selective receptor antagonists for screening a chemical database and identified two structurally novel lead compounds with satisfactory affinity for $\mathrm{ET}_{\mathrm{A}}$ receptor.

\section{Angiotensin receptors}

Angiotensins are oligopeptides that exert their biological actions through the binding to specific angiotensin receptors $\left(\mathrm{AT}_{1}, \mathrm{AT}_{2}\right.$, $\mathrm{AT}_{3}$, and $\mathrm{AT}_{4}$ receptors). It has been demonstrated that these receptors could be targeted for developing novel effective drugs for the treatment of hypertension, cardiovascular disorders, diabetic nephropathy, atherosclerosis (Goodfriend et al., 1996).

A series of symmetrically bis-substituted imidazole analogs has been designed based on docking studies, utilizing for the first time an extra hydrophobic binding cleft of the modeled $\mathrm{AT}_{1}$ receptor (Agelis et al., 2013). Four of the synthesized compounds showed high binding affinity to the $\mathrm{AT}_{1}$ receptor and high antagonistic activity (potency) similar or even superior to that of Losartan.

In an attempt to identify new $\mathrm{AT}_{1}$ receptor antagonists $\mathrm{Pal}$ and Paliwal (2012) developed a pharmacophore-based virtual screening protocol, which led to the identification of two active 
$\mathrm{AT}_{1}$ receptor antagonists with diverse structures (Pal and Paliwal, 2012).

\section{DRUG DESIGN AND DISCOVERY IN NEUROLOGICAL DISORDERS AND PAIN \\ Dopamine receptors}

Dopamine exerts its function via five different receptors $\left(D_{1}, D_{2}\right.$, $\mathrm{D}_{3}, \mathrm{D}_{4}$, and $\mathrm{D}_{5}$ receptors). This system plays a pivotal role in central nervous system and has been demonstrated to be involved in a series of neurological and psychiatric diseases such as Parkinson's disease, schizophrenia, bipolar disorder, drug addiction, and Huntington's disease (Pivonello et al., 2007; Beaulieu and Gainetdinov, 2011). The discovery of ligands able to modulate the dopaminergic system remains challenging and a lot of computational efforts were carried out for selecting potent and selective ligands.

In 2010, the crystal structure of $\mathrm{D}_{3}$ receptor was solved, which definitely confirmed the utility of homology models in GPCRs drug discovery (Chien et al., 2010). Indeed, Carlsson et al. (2011) docked over 3.3 million molecules against a homology model, and 26 of the highest ranking were tested for binding. Six had affinities ranging from 0.2 to $3.1 \mu \mathrm{M}$. Subsequently, the crystal structure was used and the docking screen repeated. Of the 25 compounds selected, five showed affinities ranging from 0.3 to 3.0 $\mu \mathrm{M}$. One of the new ligands from the homology model screen was optimized reaching an affinity to $81 \mathrm{nM}$. The paper clearly demonstrated the feasibility of high throughput docking using modeled GPCRs.

The solved crystal structure of $\mathrm{D}_{3}$ receptor with a $\mathrm{D}_{2} / \mathrm{D}_{3}$ selective antagonist provides an opportunity to identify subtle structural differences between closely related GPCRs that can be exploited for novel drug design. In an elegant work Lane etal. (2013) performed virtual screening for orthosteric and putative allosteric ligands of $\mathrm{D}_{3}$ receptor using two optimized crystal-structure-based models. The authors employed in the computational protocol a receptor with an empty binding pocket $\left(\mathrm{D}_{3}\right.$ receptor-APO), and a receptor in complex with dopamine ( $\mathrm{D}_{3}$ receptor-Dopa). Potential hits retrieved by using the two models were submitted to biological evaluation and functional characterization. Pharmacological studies showed 14 novel ligands with a binding affinity better than $10 \mu \mathrm{M}$ in the $\mathrm{D}_{3}$ receptorAPO candidate list (56\% hit rate), and eight novel ligands in the $\mathrm{D}_{3}$ receptor-Dopa list (32\% hit rate). Most ligands in the $\mathrm{D}_{3}$ receptor-APO model spanned both orthosteric and extended pockets and behaved as antagonists at $\mathrm{D}_{3}$ receptor. Among the identified ligands, one compound showed the highest potency of dopamine inhibition ( $\mathrm{IC}_{50}=7 \mathrm{nM}$ ). In contrast, compounds identified by the $\mathrm{D}_{3}$ receptor-Dopa model were predicted to bind an allosteric site at the extracellular extension of the pocket. Such compounds showed a variety of functional activity profiles. In fact, at least two compounds were non-competitive allosteric modulator of dopamine signaling in the extracellular signal-regulated kinase and $\beta$-arrestin recruitment assays. The high affinity and LE of the chemically diverse hits identified in this mentioned study evidently demonstrated the utility of structurebased screening in targeting allosteric sites of GPCRs (Lane et al., 2013).
Very recently, Vass et al. (2014) reported a prospective structure based virtual fragment screening on $\mathrm{D}_{3}$ and the $\mathrm{H}_{4}$ receptors. Representative receptor conformations for ensemble docking were obtained from molecular dynamics (MD) trajectories. Biological evaluation confirmed hit rates ranged from 16 to $32 \%$. Hits had high LE values in the range of $0.31-0.74$ and also acceptable lipophilic efficiency, demonstrating that the X-ray structure, the homology model, and structural ensembles were all found suitable for docking based virtual screening of fragments against these GPCRs.

\section{Muscarinic receptors}

The muscarinic acetylcholine receptors $\left(\mathrm{M}_{1}-\mathrm{M}_{5}\right)$ are promising targets for the treatment of chronic obstructive pulmonary disease, urinary incontinence, and diabetes. Unfortunately, the lack of subtype specificity has remained a major obstacle to develop clinically useful muscarinic ligands. Very recently, Kruse et al. (2013) used the crystal structure of the $\mathrm{M}_{2}$ and $\mathrm{M}_{3}$ receptors as a template to identify, by means of structure-based docking, novel muscarinic ligands. Interestingly, one compound was a partial agonist at the $M_{3}$ receptor without measurable $M_{2}$ agonism that was able to stimulate insulin release from a mouse $\beta$-cell line (Kruse et al., 2013).

\section{Cannabinoid (CB) receptors}

The cannabinoid 1 receptor (CB1 receptor) and the cannabinoid 2 receptor (CB2 receptor) are members of the GPCR family (Matsuda etal., 1990). Agonists of both cannabinoid receptor subtypes produce strong antinociceptive effects in animal models of chronic, neuropathic, and inflammatory pain and are intensively investigated as potential new analgesic and antiinflammatory agents. CB1 antagonists are clinically established to be effective in treating obesity, obesity-related cardio-metabolic disorders, and substance abuse, but there are currently no marketed CB1 antagonists. The relevance of CB2-mediated therapeutics is well established in the treatment of pain, neurodegenerative, and gastrointestinal tract disorders (Di Marzo, 2008; Brogi et al., 2011; Pasquini et al., 2012).

Pandey et al. (2014) used homology model and high throughput docking to discover new chemical classes of CB1 antagonists that may serve as starting point for drug development. The authors developed and validated a homology model of CB1 based on a bovine rhodopsin template, which led to the discovery of seven compounds with an inhibitory potency $>50 \%$ at $10 \mu \mathrm{M}$ (Pandey et al., 2014). Wang et al. (2008) identified a novel class of azetidinones as CB1 antagonists by also using virtual screening methods. Meng et al. (2010) reported the identification of the benzhydrylpiperazine scaffold as a potential scaffold to develop novel CB1 receptor modulators using a privileged structure-based approach. The authors identified a highly potent and selective CB1 receptor inverse agonist that was able to reduce body weight in diet-induced obese Sprague-Dawley rats.

A recent work carried out by Renault et al. (2013) highlighted the importance related to crystallization of class-A GPCRs in a range of active states, identifying specific anchoring sites for CB2 agonists retrieved in an agonist-bound homology model of CB2 receptor. Docking-scoring enrichment tests of a high-throughput 
virtual screening of 140 compounds led to 13 hits within the $\mu \mathrm{M}$ affinity range. Interestingly, a relevant number of selected hits behaved as CB2 agonists, among them two novel unrelated full agonists were identified. Notably, the exclusive discovery of agonists illustrated the reliability of this agonist-bound state model in the discovery of GPCR ligands with desired behavior (Renault et al., 2013).

Recently, some of us described a three-dimensional quantitative structure-selectivity relationships (3D-QSSR) study for selectivity of a series of structurally diverse ligands characterized by a wide range of selectivity index values for cannabinoid CB1 and CB2 receptors (Brogi et al., 2011). 3D-QSSR explorations were expected to provide design information for the design of selective CB2 ligands. The computational model proved to be predictive, with $r^{2}$ of 0.95 and $Q^{2}$ of 0.63 . In order to get prospective experimental validation, the selectivity of an external data set of 39 compounds reported in the literature was predicted by means of 3D-QSSR model $\left(r^{2}=0.56\right)$. Subsequently, a quinolone derivative predicted to be a selective CB2 ligand was synthesized and found to be an extremely selective CB2 ligand displaying high $\mathrm{CB} 2$ affinity $(K i=4.9 \mathrm{nM})$, while being devoid of CB1 affinity $(K i>10,000 \mathrm{nM})$. This finding confirmed that the ligand-based tool represent a valuable complementary approach to docking studies performed on homology models of GPCRs.

\section{Opioid receptors}

Opioids are key medications for the treatment of pain.The $\mu$-opioid receptors (MORs), $\delta$-opioid receptors (DORs), $\kappa$-opioid receptors (KORs), and nociceptin-opioid receptor (NOP) have been isolated and cloned. The receptors were found throughout the peripheral and central nervous system. Their important role in mediating pain, drug addiction, and depression has been established. Very recently crystal structures of all classes of opioid receptor have been solved (Granier et al., 2012; Manglik et al., 2012; Thompson et al., 2012; Wu et al., 2012; Fenalti et al., 2014). Below is reported one of the first computational efforts using the crystal structure of the KOR.

Negri et al. (2013) applied a structure-based computational protocol using the crystal structure of KOR receptor, discovering a selective novel KOR agonist, exhibiting analgesic effects without activating reward pathways. Remarkably, the novel derivatives have been identified as novel pharmacological tools to study the involvement of KOR in the etiology of drug addiction, depression, and pain (Negri et al., 2013).

\section{ALLOSTERIC MODULATORS AND BIVALENT LIGANDS ALLOSTERIC MODULATORS}

The binding site of the endogenous agonist is qualified as orthosteric. In general, antagonists, and inverse agonists typically occupy also this site, which is usually buried at the core of the receptor or located at its extracellular N-terminal end. In addition, exist allosteric sites that bind synthetic drugs or endogenous mineral cations, such as sodium, calcium, zinc, and magnesium, which can also modulate the activity of the receptor (Christopoulos, 2002). More specifically, allosteric ligands may promote or reduce the binding of orthosteric ligands. Their effects on receptor activation could be in a positive, negative, or neutral manner. Allosteric modulators offer several advantages over classical approaches. Allosteric modulator can modulate affinity via conformational coupling between the orthosteric and allosteric binding sites or modulate efficacity by altering the functional response of the receptor to orthosteric ligand binding. These mechanisms can be dominant for a particular allosteric drug candidate and have significant value in the drug development process. Allosteric modulators can have a chemical structure unrelated to that of competitive agonist or antagonist drugs, offering a novel class of small molecule drug candidates.

The orthosteric binding sites within A class GPCR family are highly conserved due to the evolutionary pressure to retain amino acid sequences necessary for binding of the endogenous ligand. In contrast, allosteric modulator binding sites have much greater structural diversity than endogenous ligand binding sites, displaying a very high selectivity for a receptor subtype (Mohr et al., 2013).

Negative allosteric modulators (NAMs) bind at the allosteric binding site to inhibit the efficacy or affinity to the orthosteric binding site of the agonists while they have no intrinsic agonist efficacy. Two mechanisms can be invoked: the NAMs may stabilize an inactive conformation of the receptor that lowers the affinity of the agonists, or alternatively they raise the energy barrier necessary to activate the receptor activation, which diminishes the intensity of the output response (Figure 2, Burford et al., 2011).

On the very opposite, the binding of positive allosteric modulators (PAMs) to their allosteric binding site promotes the binding of the agonists at the orthosteric site or lower the barrier of energy involved in the shift to the active conformation of the receptor (Burford etal., 2011). The major drawback with this class of drugs is that they do not display any pharmacological effect in the absence of the endogenous (or exogenous) orthosteric agonist. Hence, a PAM in combination with an orthosteric agonist can increase the efficacy of the orthosteric compound. The PAM can allow a decrease in the dose administered, thereby improving the overall side-effect profile (Figure 2).

Silent allosteric modulators (SAMs) are neutral allosteric ligands. They have no effect on orthosteric agonist affinity or efficacy. However, SAMs can act as competitive antagonists at the same allosteric site, blocking PAM or NAM activity. SAMs can be effective tools to show that presumed PAM or NAM effects are receptor-mediated (Burford et al., 2013).

Interestingly, minor structural modifications are sufficient to transform a NAM into a PAM. Such a subtle effect have not been reported yet with class A GPCRs, even though it is likely that it will be found in a close future, due to the growing importance of this field of research. A striking example of this phenomenon concerns allosteric ligands of metabotropic glutamate receptors (mGluR5), class C family of the GPCRs, (Figure 2). While compound 1 is a partial NAM that only partially block mGluR5 signaling, introduction of a mere methyl can convert this compound to a full NAM or PAM (Williams et al., 2010).

Already two NAMs and one PAM have been approved for clinical use: Maraviroc (Celsentry), plerixafor (Mozobil), and Cinacalcet (Mimpara; Figure 3). Maraviroc is a high-affinity 


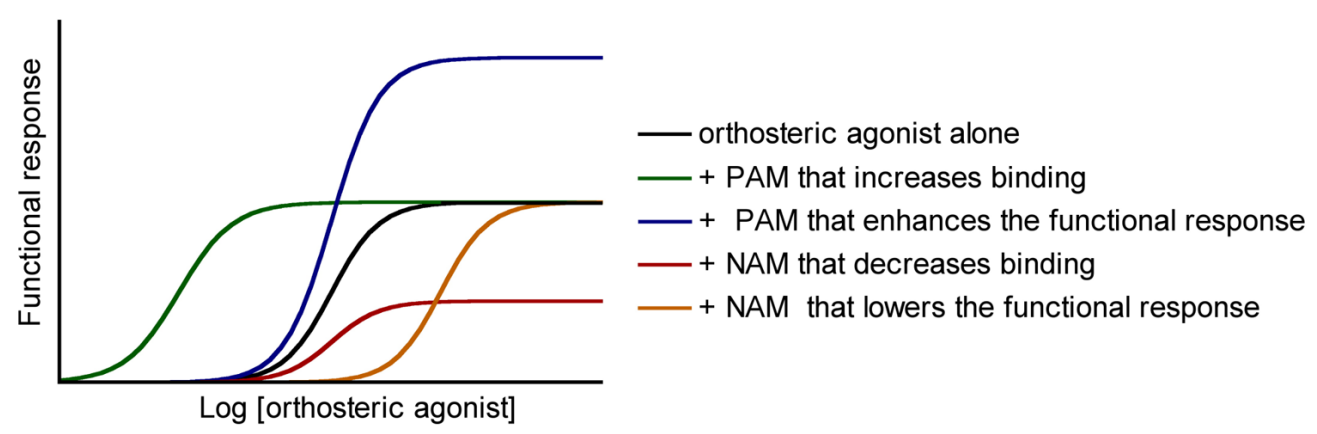

FIGURE 2 | Functional responses of allosteric modulators. Positive and negative allosteric modulators (positive allosteric modulators and negative allosteric modulators) may modulate the affinity and/or the efficacy of orthosteric agonists.

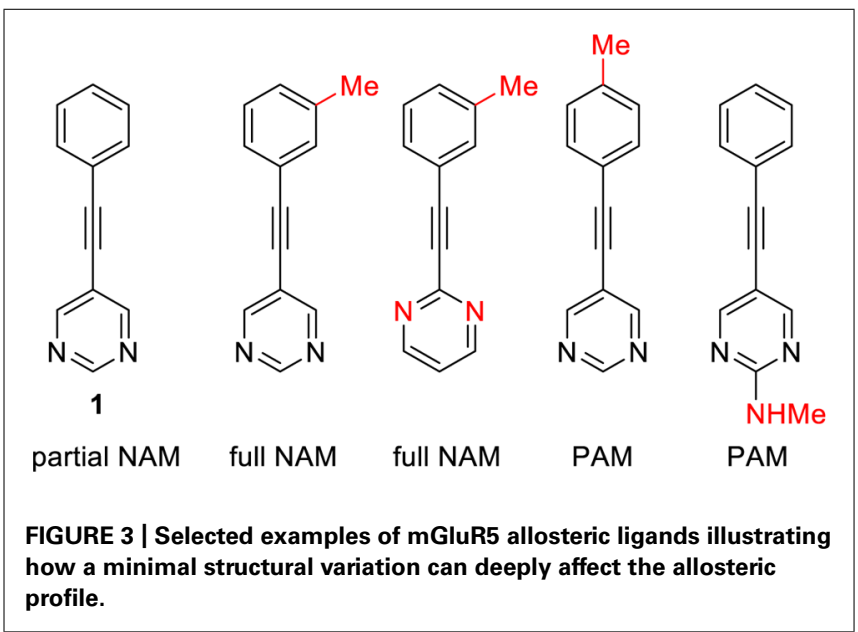

NAM of the CCR5 receptor that blocks the interaction of the HIV-glycoprotein 120 with this receptor (Fatkenheuer et al., 2005). It was approved in 2007 for the treatment of HIV in combination with antiretroviral agents. Plerixafor is a NAM of the chemokine receptor CXCR4. This medicine is used to promote the release stem cells into the bloodstream after autologous stem cell transplantation (Scholten et al., 2012).

Cinacalcet is a PAM of the calcium-sensing receptor (CaSR) of parathyroid hormone (PTH) producing cells. In a feedback mechanism, activation of CaSR by cinacalcet inhibits PTH release.
This medicine was approved in 2004 for the treatment of secondary hyperparathyroidism in patients with chronic kidney disease on dialysis, and hypercalcaemia in patients with parathyroid cancer (Torres, 2006).

\section{MONOVALENT LIGANDS SPECIFIC FOR GPCR HETERODIMERS}

It is now well established that GPCRs may form homodimers, heterodimers, or oligomers. Even though their physiological function is not fully apprehended, these dimerizations and oligomerizations have major repercussions on ligand binding, activation of signaling pathways and cellular trafficking. Therefore, targeting specific GPCR dimers may provide drugs with enhanced potency, selectivity, and therapeutic index. Two types of such drugs that are specific for a specific GPCR dimer have been described (Figure 4). The first type concerns monovalent drugs, such as $6^{\prime}$-guanidinonaltrindole (6'GNTI), NNTA or SKF83959, that bind to only one receptor at a time. The second one concerns bivalent drugs that bind to two receptors at the same time (Figures 4 and 5).

Waldhoer etal. (2005) found that 6'-GNTI behaves as an extremely potent agonist in cells expressing both DORs and MORs and established that this drug selectively activates the $\delta \mathrm{OR}-\kappa \mathrm{OR}$ heterodimer (Waldhoer et al., 2005). In vivo, 6'-GNTI induces a potent analgesia when administered intrathecally. This $\delta \mathrm{OR}-$ $\kappa \mathrm{OR}$ heterodimer was found to be expressed in a tissue selective fashion suggesting that such a drug may induce less side effects than classical OR agonists. Similarly, NNTA selectively activates<smiles>Cc1nnc(C(C)C)n1C1CC2CCC(C1)N2CC[C@H](NC(=O)C1CCC(F)(F)CC1)c1ccccc1</smiles><smiles></smiles><smiles>CCCCCCCCCCCN[C@@H](C)c1cccc2ccccc12</smiles>

FIGURE 4 | Structure of approved allosteric modulators. 


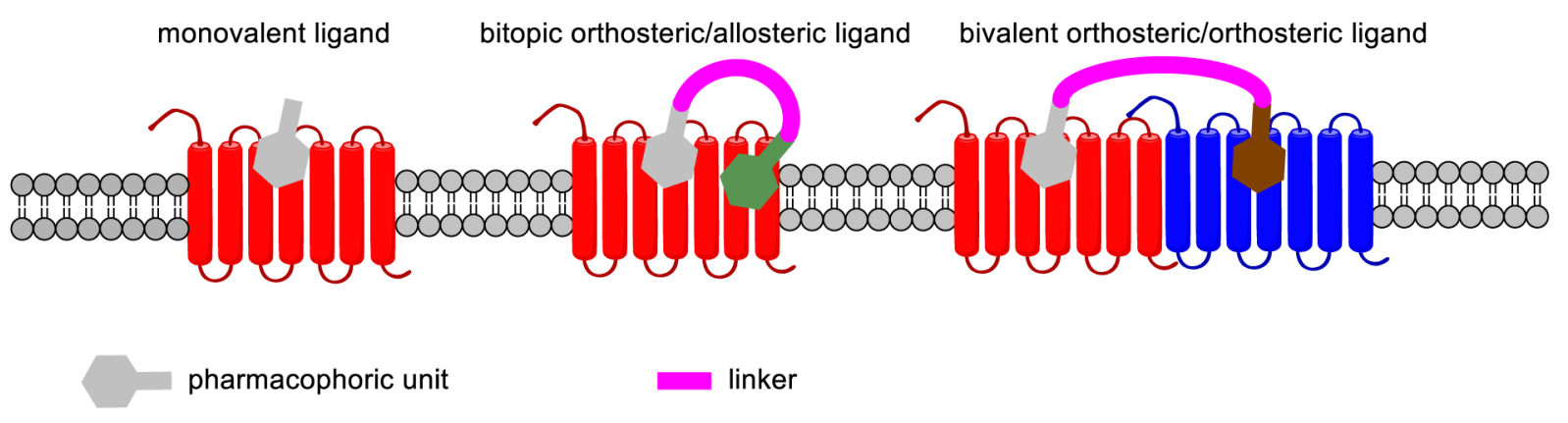

FIGURE 5 | Binding mode of monovalent, bitopic orthosteric/allosteric, and bivalent orthosteric/allosteric ligands of GPCRs.

the $\mu \mathrm{OR}-\kappa \mathrm{OR}$ heterodimer to induce a potent antinociceptive response devoid of physical dependence in mice (Yekkirala et al., 2011).

Another interesting example is provided by SKF83959 that selectively targets the $D_{1}-D_{2}$ dopaminergic heterodimer to increase intracellular calcium levels through activation of $\mathrm{G}_{\mathrm{q} / 11}$ (Rashid et al., 2007). Interestingly, this drug does not activate adenylyl cyclase, which is normally induced by the signaling of $\mathrm{D}_{1}$ or $\mathrm{D}_{2}$ receptors.

\section{BIVALENT LIGANDS}

Different domains of GPCRs such as intracellular loops (ICL), extracellular loops (ECL), and transmembrane domains (TM) are known to participate in ligand recognition and receptor dimerization. Many GPCRs can form oligomers with conformational rearrangements of the receptors that impact their signaling (Percherancier et al., 2005).

Bivalent ligands are composed of two pharmacophoric units connected through a linker (while monovalent drugs encompass only one pharmacophoric unit). The pharmacophores may be identical (and in that case, the ligand is termed as homobivalent) or different in the case of heterobivalent ligands. These pharmacophoric units may either bind to the orthosteric site and an allosteric site within the same receptor or to two orthosteric binding sites located on two different receptors (Figure 6).
Often the large size and molecular weight of bivalent ligands severely reduce their bioavailability and hinder their use in in vivo studies. However, these limitations are not irretrievable and few bivalent ligands have shown interesting in vivo pharmacological activities, even though none of them entered a clinical trial (Figure 7).

Portoghese and colleagues have conjugated a $\mu$ agonist (oxymorphone) to a $\delta$ antagonist of opioids receptors (naltrindole) through a 21-atom linker (Daniels et al., 2005). The resulting compound, MDAN-21, was able to cross the blood brain barrier to induce antinociception. Impressively, this drug was 50 times more potent than morphine, and did not induce tolerance or physical dependence after chronic treatment.

In another example, Halazy and colleagues dimerized a 5- $\mathrm{HT}_{1 \mathrm{~B}}$ agonist, sumatriptan, through a linker to obtain an orally active drug that induced a stronger hypothermia than sumatriptan itself (Perez etal., 1998). It is remarkable that such a drug could cross the blood-brain barrier in spite of its elevated molecular weight, polar surface area, and number of hydrogenbond donors, suggesting that an active transport is probably involved.

SR141716 is another interesting bivalent drug that combines two units of a cannabinoid CB1 receptor antagonist/inverse agonist (Zhang et al., 2010). This compound was found to efficiently cross the blood-brain barrier to inhibit the antinociceptive effects of a cannabinoid agonist.<smiles></smiles>

6'GNTI<smiles>O=C(N[C@H]1CC[C@@]2(O)[C@H]3Cc4ccc(O)c5c4[C@@]2(CCN(CC2CC2)C5)[C@H]1O3)c1ccc2ccccc2c1</smiles>

NNTA<smiles>Cc1cccc(C2CN(C)CCc3c2cc(O)c(O)c3Cl)c1</smiles>

SKF83959

FIGURE 6 | Structure of monovalent drugs acting on GPCR dimers. 


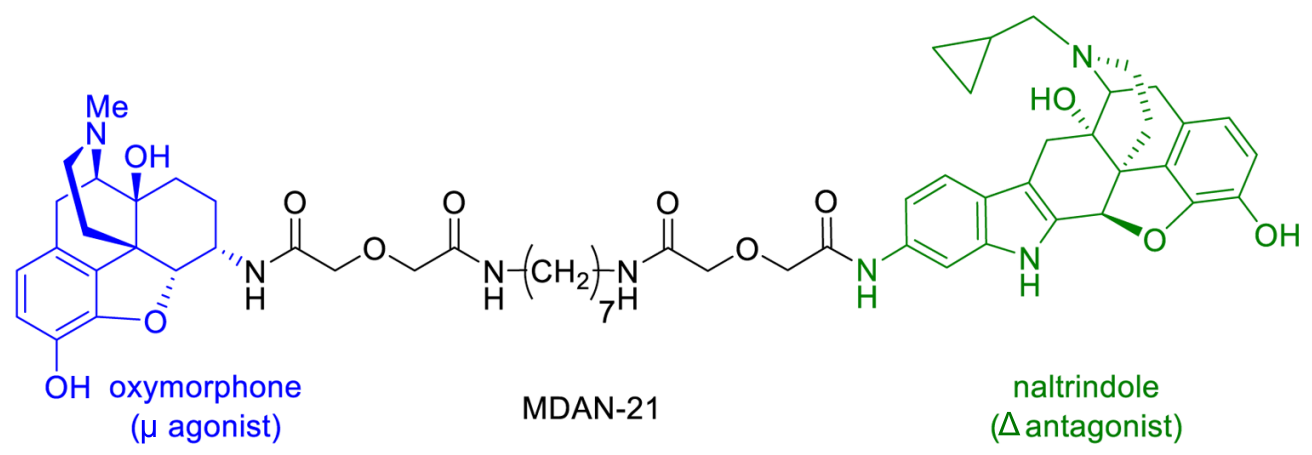<smiles>[R15]CCCCCCCNC(=O)c1nn(-c2ccc(Cl)cc2Cl)c(-c2ccc(Cl)cc2)c1C</smiles><smiles></smiles>

adenosine

FIGURE 7 | Structure of bivalent ligands that display in vivo pharmacological activities.

Very recently, Christopoulos and colleagues conjugated adenosine to VCP171, a PAM of the adenosine $\mathrm{A} 1$ receptor $\left(\mathrm{A}_{1 \mathrm{~A}} \mathrm{R}\right.$; Valant et al., 2014). The obtained compound, called VCP746 binds to both the orthosteric and allosteric sites and behaves as a biased agonist (Figure 7). Importantly, it protects in vitro cardiomyoblasts and cardiomyocytes against simulated ischemia, but in contrast to classical $\mathrm{A}_{1 \mathrm{~A}} \mathrm{R}$ agonists it does not perturb rat atrial heart rate in vivo.

\section{BIASED-SIGNALING SELECTIVITY}

$G$ protein-coupled receptors ligands are described by their efficacy (agonist, antagonist, partial agonist, or inverse agonist) and target (receptor type and subtype). Recently, great attention has been devoted to functional selectivity of GPCR ligands for the development of better therapeutic drugs with potentially fewer off-target and/or side effects. Ligand bias has been described based on their functional selectivity that preferentially signal through either $G$ protein- or $\beta$-arrestin-mediated pathways.

Allosteric ligands can induce biased $G$ protein signaling, thus representing interesting opportunities for drug discovery. Moreover, biasing $\beta$-arrestin-dependent signaling has also been shown to be potentially beneficial in heart diseases.

To delineate the contributions of $G$ proteins and $\beta$-arrestins to GPCR function several approaches have been used including targeted genetic deletion of GRKs or $\beta$-arrestins, RNA silencing of $\mathrm{G}$ protein and $\beta$-arrestin, and small-molecule inhibitors of specific signal transduction pathways (DeWire etal., 2007). An important approach to investigate whether GPCR ligands are $G$ protein-biased or $\beta$-arrestin-biased agonists is the use of $\beta$-arrestin knockout mice (Rominger et al., 2014). Indeed, the recapitulation of improved pharmacology in $\beta$-arrestin $\mathrm{KO}$ mice by a ligand demonstrates that this ligand is a G-protein biased 
ligand and may be particularly sensitive to the acute desensitization effects of $\beta$-arrestin. Inversely, minor pharmacological effects in $\beta$-arrestin $\mathrm{KO}$ mice indicate that $\beta$-arrestin is required for the specific intracellular signaling pathways of these $\beta$-arrestin-biased ligands.

Biased ligands that selectively activate $\beta$-arrestin signaling pathways over $\mathrm{G}_{\mathrm{q}} \mathrm{G}_{\mathrm{i}}$ and $\mathrm{G}_{\mathrm{s}}$-coupled GPCRs have already been reported (Violin and Lefkowitz, 2007; Gesty-Palmer et al., 2009). Biased signaling can also results from mutation of receptors (Leach et al., 2012; Sbai et al., 2014; Figure 8).

Another advanced approach is receptor activated solely by synthetic ligand' (RASSLs). The chemical genetic approach involves the expression of a mutant form that can be activated by synthetic drugs but not by the endogenous ligands. For example a specifically mutated muscarinic receptor can be activated by clozapine- $N$-oxide $(\mathrm{CNO})$, but not by acetylcholine (Armbruster et al., 2007). This approach has been utilized to determine GPCR signaling pathways important in $\beta$-islet function (Guettier et al., 2009), neuronal networks involved in neurological responses such as locomotion learning and memory (Garner et al., 2012), limbic seizures, and metabolism (Kong et al., 2012).

\section{G PROTEIN-BIASED MORPHINE $\mu$-OPIOID RECEPTOR (MOR) LIGANDS}

Both MOR and DOR are involved in analgesic effect of opioids. Thermal nociception is primarily modulated by MORs while mechanical nociception is primarily mediated by DOR (Scherrer etal., 2009), suggesting that these receptors are expressed in distinct circuits. Opioids cause postoperative nausea and vomiting, constipation, and sedation, giving significant patient discomfort, and can prolong hospital stay (Anastassopoulos etal., 2011). The respiratory suppression also limits opioid dosing, leaving many patients in pain during recuperation (Dahan, 2007). The classical $\mu$ opioid morphine increases efficacy and duration of analgesic response with reduced gastrointestinal dysfunction, and less respiratory suppression in $\beta$-arrestin-2 knockout mice compared to wild-type mice. This data clearly suggested that G protein-biased MOR agonists would be more efficacious with reduced adverse than current opioids.
The $G$ protein-biased MOR agonist TRV130 has robust $G$ protein signaling, with less $\beta$-arrestin recruitment and receptor internalization. TRV130 increases analgesia with reduced CNS depression and reduced gastrointestinal dysfunction compared with morphine. Thus TRV130 may provide a marked improvement over current opioids in postoperative care. It also holds great promise for chronic pain management, where constipation is a severe and often dose-limiting adverse event. TRV130 has been currently evaluated in human clinical trials for the treatment of acute severe pain (Chen et al., 2013). TRV130 displays broad dose margins between MOR-mediated pharmacology and intolerance in healthy volunteers (Soergel et al., 2014).

Similarly, a $\beta$-arrestin-MAPK pathway mediates stress and aversion-associated effects of kappa opioid receptor agonists, suggesting that biased kappa opioid ligands could provide analgesia without the dysphoric effects associated with classic kappa opioid agonists (Bruchas et al., 2010).

\section{$\boldsymbol{\beta}$-ARRESTIN-BIASED DOPAMINE $\boldsymbol{D}_{\mathbf{2}}$ LIGANDS}

Dopamine plays a major role in reward-motivated behavior and motor control. The physiological actions of dopamine are mediated by five distinct but closely related GPCRs that are divided into two major groups: the $\mathrm{D}_{1}$ and $\mathrm{D}_{2}$ classes of dopamine receptors (Vallone etal., 2000). This classification is generally based on the original biochemical observations showing that dopamine is able to modulate adenylyl cyclase (AC) activity. Non-canonical modes of dopamine $\mathrm{D}_{2}$ receptor $\left(\mathrm{D}_{2} \mathrm{R}\right)$ signaling via $\beta$-arrestin is important for the therapeutic actions of both antipsychotic and antimanic agents. Aripiprazole, a FDA-approved atypical antipsychotic drug, was one of the first functionally selective $\mathrm{D}_{2} \mathrm{R}$ ligands identified (Urban et al., 2007; Mailman and Murthy, 2010). However, aripiprazole could behave as a full agonist, a partial agonist, or an antagonist at $\mathrm{D}_{2} \mathrm{R}$ depending on the cell type (Shapiro etal., 2003; Urban et al., 2007).

It was found that the antipsychotic action of an aripiprazole analog, UNC9975, was attenuated in the $\beta$-arrestin-2 knockout mice. UNC9975 also represents unprecedented $\beta$-arrestin-biased ligands for a $\mathrm{G}_{\mathrm{i}}$-coupled GPCR. Significantly, UNC9975 is an

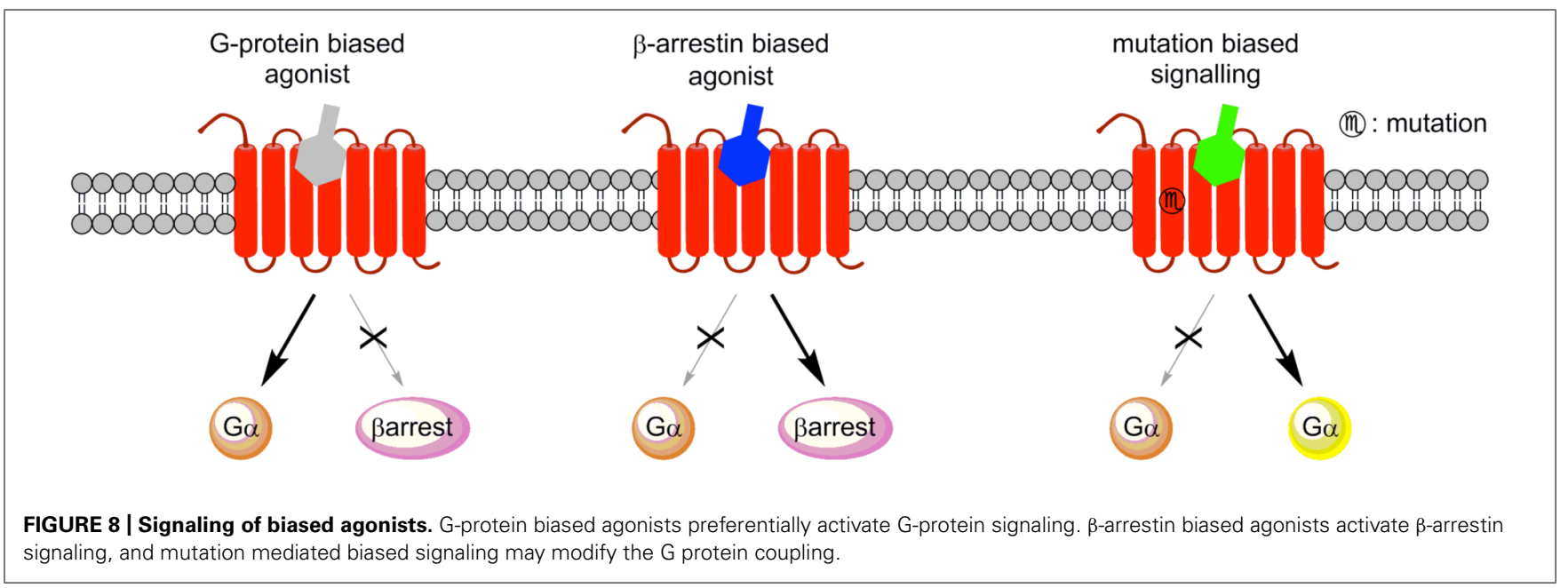


antagonist of $\mathrm{G}_{\mathrm{i}}$-regulated cAMP production and partial agonist for $\mathrm{D}_{2} \mathrm{R} / \beta$-arrestin- 2 interactions. Importantly, UNC9975 displayed potent antipsychotic-like activity without inducing motoric side effects in vivo (Masri et al., 2008). This $\beta$-arrestinbiased ligand shows a potent ability to suppress both $d$ amphetamine and phencyclidine-induced hyper locomotion in mice, indicating that it possesses antipsychotic activities in vivo. $\beta$-arrestin-biased ligands induce a lack of internalization. Thus, we can assume that drugs that induce internalization would ultimately foster tachyphylaxis and receptor down-regulation (Allen and Roth, 2011).

\section{MISSENSE MUTATION GPCR LEADING BIASED SIGNALING IN DISEASES}

Many biased signaling are due to the ligand (Whalen et al., 2011), but few examples of biased signaling induced by a mutation of receptors have also been reported (Rajagopal et al., 2010).

A natural mutation leading to biased signaling has been identified in the thyroid stimulating hormone (TSH) receptor gene. The mutant TSH receptor still couples to $\mathrm{G}_{\mathrm{s}}$ and activates cAMP but completely loses $\mathrm{G}_{\mathrm{q}}$-mediated inositol phosphate production. This mutation on TSH receptor causes euthyroid hyperthyrotropinemia with increased radioiodine uptake (Grasberger et al., 2007).

Another example is the natural mutations in the human calcium sensing receptor that activate both $\mathrm{G}_{\mathrm{q}}$-dependent production of inositol phosphate and the $\mathrm{G}_{\mathrm{q}^{-}}$and $\mathrm{G}_{\mathrm{i} / \mathrm{o}}$-dependent phosphorylation of ERK (Leach etal., 2012; Nygaard et al., 2013). It is generally assumed that biased signaling is an intrinsic property of a given ligand-GPCR complex, whereby a GPCR exists in several conformations, each of which is preferentially stabilized and activated by selective ligands (Nygaard et al., 2013). Likewise, the mutations leading to biased signaling are supposed to affect the equilibrium between the different receptor conformations.

The mutations in the GPCRs can lead to biased downstream signaling and may induce pathogenic and, in some cases, protective roles.

Prokineticins are anorexigenic and angiogenic hormones that couple to two GPCRs, PKR1, and PKR2 (Nebigil, 2009; Dormishian et al., 2013; Szatkowski et al., 2013). Mutations in the prokineticin receptor 2 (PKR2) have been found in $10 \%$ of patients with Kallmann syndrome that is characterized by hypogonadotropic hypogonadism. To date, 21 missense mutations of PKR2 have been identified in Kallmann syndrome patients. Some of these mutations are related with the $\mathrm{G}_{\mathrm{q}}$-dependent signaling pathway (Sinisi etal., 2008; Abreu etal., 2012; Sbai et al., 2014). However, certain mutations on this receptor affect $\beta$-arrestin recruitment (R80C) or the $G_{q}$ and $G_{i}$ signaling pathways (R164Q) with normal $\mathrm{G}_{\mathrm{s}}$ signaling. The $\mathrm{G}_{\mathrm{q}}$-dependent signaling defect of the $\mathrm{R} 164 \mathrm{Q}$ receptor makes this mutation most likely pathogenic. The mutation $\mathrm{R} 268 \mathrm{C}$ affecting a residue in the third intracellular loop of the receptor selectively impairs $\mathrm{G}_{\mathrm{i} / \mathrm{o}}$-dependent signaling of the receptor and is considered nonpathogenic (Sbai etal., 2014). It remains unclear whether the $\beta$-arrestin-dependent signaling defect for the R80C mutation on PKR2 has a pathogenic effect with respect to Kallmann syndrome.

\section{BIASED LIGANDS IN DISEASES}

Two GPCRs, the angiotensin II (AngII) type 1 receptor $\left(\mathrm{AT}_{1} \mathrm{R}\right)$ and the $\beta$-ARs are targets of widely used cardiovascular drugs. They are now potential therapeutic targets for biased ligands (DeWire and Violin, 2011).

The peptide hormone angiotensin II (AngII) is a vasopressor that regulates salt and fluid homeostasis, modulating vasoconstriction, and aldosterone secretion, as well as thirst and inflammation (Benigni et al., 2010). Angiotensin-converting enzyme inhibitors that lower AngII levels and angiotensin receptor blockers are widely used in treating hypertension and other cardiovascular diseases. The $\mathrm{AT}_{1} \mathrm{R}$ couples primarily to $\mathrm{G}_{\alpha \mathrm{q}}$ signaling, leading to phosphatidylinositol bisphosphate hydrolysis, generating diacylglycerol, mobilizing calcium, and activating signaling enzymes such as protein kinase $C . A_{1} R$ is also involved in $\beta$-arrestin-dependent signals, activation of epidermal growth factor receptor transactivation, Src, and JAK/STAT (Saito and Berk, 2001; Wei etal., 2003; Oliveira et al., 2007). One body of evidence for distinct $\mathrm{AT}_{1} \mathrm{R}$ signaling came from receptor mutagenesis. $\mathrm{AT}_{1} \mathrm{R}$ effects can be divided into distinct G-protein-dependent and G-protein-independent signals in vivo. Reduction or elimination of $\beta$-arrestin-1 or $\beta$ arrestin-2 expression with siRNA in vitro or genetic deletion in vivo showed that cardioprotective effect of $\mathrm{AT}_{1} \mathrm{R}$ is mediated by $\beta$-arrestin- 2 signaling. TRV120027, a selective and $\beta$-arrestin-biased $\mathrm{AT}_{1} \mathrm{R}$ ligand blocks AngII-dependent hypertension while increasing cardiomyocyte contractility, promoting cytoprotective, or antiapoptotic signals and preserving kidney function to provide a great benefit in acute heart failure (Monasky etal., 2013). TRV120027 is now in clinical trials for the treatment of acute heart failure (Soergel et al., 2014).

Endothelins play a key role in vascular homeostasis. $\mathrm{ET}_{\mathrm{A}}$ and $\mathrm{AT}_{1}$ receptor antagonists both lower blood pressure in hypertensive patients. Accordingly, a dual $\mathrm{ET}_{\mathrm{A}}$ and $\mathrm{AT}_{1}$ receptor antagonist may be more efficacious antihypertensive drug than current medicines.

Epinephrine binds to cardiac $\beta_{1} A R$ and stimulates inotropy through G-protein signals, resulting in increased heart rate, blood pressure, and metabolic stress, promoting cardiomyocyte apoptosis. Several studies demonstrated that $\beta_{1} A R$ G-protein and $\beta$-arrestin pathways normally strike a balance between apoptosis associated with prolonged inotropy and counteracting cardioprotection. When this balance is disrupted in the absence of $\beta$-arrestin signaling, apoptosis increases and cardiac function decreases. Activation of $\beta$-arrestin scaffolded calcium/calmodulin-dependent kinase II by the $\beta_{1} \mathrm{AR}$ requires cAMP, thus the net effect of a $\beta$-arrestin-biased ligand is cardioprotective.

A biased ligand for $\beta_{1} \mathrm{AR}$, carvedilol activates the cardioprotective $\beta$-arrestin-mediated epidermal growth factor receptor transactivation-signaling pathway. Carvedilol has shown potentially superior clinical efficacy over other $\beta$-blockers in terms of cardiovascular events after myocardial infarction (Kopecky, 2006) and perhaps mortality (Poole-Wilson etal., 2003). The contributions of function of GRK/ $\beta$-arrestin to the clinical efficacy of carvedilol remain unclear. 
Collectively, substantial data suggest that biased ligands will have distinct and perhaps more beneficial effects than unbiased agonists. Biased signaling is proposed to be useful in several diseases, including heart failure ( $\beta$-ARs), hypertension $(\alpha$-ARs), neuropsychiatric and/or neurodegenerative disorders (histamine $\mathrm{H}_{1}$ receptors), schizophrenia, Parkinson's disease (dopamine receptors), psychosis and depression (serotonin receptors), hypothyroidism (TSH receptor), hyperlipidemia (nicotinic acid receptor), diabetes (GLP1). However, it is possible that biased signaling could be associated with undesirable side effects and even contribute to disease. For example, the bacterium Neisseria meningitidis interacts in a biased and allosteric manner with the $\beta_{2} \mathrm{AR}$ to initiate signaling cascades that facilitate meningeal colonization (Brissac et al., 2012).

\section{CONCLUSION}

A substantial increase in our understanding of GPCR pharmacology has provided an array of ligands that target both orthosteric and allosteric sites of GPCRs as well as ligands that have properties of bias stimuli. The recent identification of a PAM and NAM binding site, together with the synthesis of in vivo effective ligands, represents a novel, and likely more favorable, option for pharmacological manipulations of the GPCRs. Biased ligands offer safer, better-tolerated, and more efficacious drugs. However, in some cases a path to successful drug development for targets that have been abandoned because of on-target adverse pharmacology in the clinical proof-of-concept studies due to additional receptor signaling and regulatory mechanisms rather than $\beta$-arrestin pathway.

The complexity of GPCR signaling requires a synergistic role for experimental and computational methods in producing novel therapeutics with maximal clinical efficacy and lowest toxicity. Combining computational methods with sophisticated transgenic and chemical genetic animal models, the next generation of GPCR ligands will unquestionably employ rational design principles to deliver GPCR ligands with minimal side-effects.

\section{ACKNOWLEDGMENTS}

The authors were supported by the Centre National de la Recherche Scientifique, Fondation pour la Recherche Médicale, Medalis/Labex, Oséo and Région Alsace.

\section{REFERENCES}

Abagyan, R., and Totrov, M. (2001). High-throughput docking for lead generation. Curr. Opin. Chem. Biol. 5, 375-382. doi: 10.1016/S1367-5931(00) 00217-9

Abbas, A., and Roth, B. L. (2008). Arresting serotonin. Proc. Natl. Acad. Sci. U.S.A. 105, 831-832. doi: 10.1073/pnas.0711335105

Abreu, A. P., Noel, S. D., Xu, S., Carroll, R. S., Latronico, A. C., and Kaiser, U. B. (2012). Evidence of the importance of the first intracellular loop of prokineticin receptor 2 in receptor function. Mol. Endocrinol. 26, 1417-1427. doi: 10.1210/me.2012-1102

Agelis, G., Resvani, A., Koukoulitsa, C., Tumova, T., Slaninova, J., Kalavrizioti, D., et al. (2013). Rational design, efficient syntheses and biological evaluation of $N, N^{\prime}$-symmetrically bis-substituted butylimidazole analogs as a new class of potent Angiotensin II receptor blockers. Eur. J. Med. Chem. 62, 352-370. doi: 10.1016/j.ejmech.2012.12.044

Allen, J. A., and Roth, B. L. (2011). Strategies to discover unexpected targets for drugs active at G protein-coupled receptors. Annu. Rev. Pharmacol. Toxicol. 51, 117-144. doi: 10.1146/annurev-pharmtox-010510-100553
Anastassopoulos, K. P., Chow, W., Ackerman, S. J., Tapia, C., Benson, C., and Kim, M. S. (2011). Oxycodone-related side effects: impact on degree of bother, adherence, pain relief, satisfaction, and quality of life. J. Opioid Manag. 7, 203-215. doi: 10.5055/jom.2010.0063

Andrews, S. P., Brown, G. A., and Christopher, J. A. (2014). Structure-based and fragment-based GPCR drug discovery. ChemMedChem 9, 256-275. doi: $10.1002 / \mathrm{cmdc} .201300382$

Armbruster, B. N., Li, X., Pausch, M. H., Herlitze, S., and Roth, B. L. (2007). Evolving the lock to fit the key to create a family of $G$ protein-coupled receptors potently activated by an inert ligand. Proc. Natl. Acad. Sci. U.S.A. 104, 5163-5168. doi: 10.1073/pnas.0700293104

Beaulieu, J. M., and Gainetdinov, R. R. (2011). The physiology, signaling, and pharmacology of dopamine receptors. Pharmacol. Rev. 63, 182-217. doi: $10.1124 /$ pr. 110.002642

Beaulieu, J. M., Sotnikova, T. D., Marion, S., Lefkowitz, R. J., Gainetdinov, R. R., and Caron, M. G. (2005). An Akt/beta-arrestin 2/PP2A signaling complex mediates dopaminergic neurotransmission and behavior. Cell 122, 261-273. doi: 10.1016/j.cell.2005.05.012

Benigni, A., Cassis, P., and Remuzzi, G. (2010). Angiotensin II revisited: new roles in inflammation, immunology and aging. EMBO Mol. Med. 2, 247-257. doi: 10.1002/emmm.201000080

Brissac, T., Mikaty, G., Dumenil, G., Coureuil, M., and Nassif, X. (2012). The meningococcal minor pilin PilX is responsible for type IV pilus conformational changes associated with signaling to endothelial cells. Infect. Immun. 80, 32973306. doi: 10.1128/IAI.00369-12

Brogi, S., Corelli, F., Di Marzo, V., Ligresti, A., Mugnaini, C., Pasquini, S., et al. (2011). Three-dimensional quantitative structure-selectivity relationships analysis guided rational design of a highly selective ligand for the cannabinoid receptor 2. Eur. J. Med. Chem. 46, 547-555. doi: 10.1016/j.ejmech.2010.11.034

Brogi, S., Kladi, M., Vagias, C., Papazafiri, P., Roussis, V., and Tafi, A. (2009). Pharmacophore modeling for qualitative prediction of antiestrogenic activity. J. Chem. Inf. Model. 49, 2489-2497. doi: 10.1021/ci900254b

Brogi, S., Papazafiri, P., Roussis, V., and Tafi, A. (2013). 3D-QSAR using pharmacophore-based alignment and virtual screening for discovery of novel MCF-7 cell line inhibitors. Eur. J. Med. Chem. 67, 344-351. doi: 10.1016/j.ejmech.2013.06.048

Bruchas, M. R., Land, B. B., and Chavkin, C. (2010). The dynorphin/kappa opioid system as a modulator of stress-induced and pro-addictive behaviors. Brain Res. 1314, 44-55. doi: 10.1016/j.brainres.2009.08.062

Burford, N. T., Clark, M. J., Wehrman, T. S., Gerritz, S. W., Banks, M., O’Connell, J., et al. (2013). Discovery of positive allosteric modulators and silent allosteric modulators of Pharmacophore modeling for qualitative prediction of antiestrogenic activity-opioid receptor. Proc. Natl. Acad. Sci. U.S.A. 110, 10830-10835. doi: 10.1073/pnas.1300393110

Burford, N. T., Watson, J., Bertekap, R., and Alt, A. (2011). Strategies for the identification of allosteric modulators of G-protein-coupled receptors. Biochem. Pharmacol. 81, 691-702. doi: 10.1016/j.bcp.2010.12.012

Cappelli, A., Manini, M., Valenti, S., Castriconi, F., Giuliani, G., Anzini, M., et al. (2013). Synthesis and structure-activity relationship studies in serotonin 5-HT(1A) receptor agonists based on fused pyrrolidone scaffolds. Eur. J. Med. Chem. 63, 85-94. doi: 10.1016/j.ejmech.2013.01.044

Carlsson, J., Coleman, R. G., Setola, V., Irwin, J. J., Fan, H., Schlessinger, A., et al. (2011). Ligand discovery from a dopamine $\mathrm{D}_{3}$ receptor homology model and crystal structure. Nat. Chem. Biol. 7, 769-778. doi: 10.1038/nchembio.662

Castelli, M. P., Casu, A., Casti, P., Lobina, C., Carai, M. A., Colombo, G., et al. (2012). Characterization of COR627 and COR628, two novel positive allosteric modulators of the GABA(B) receptor. J. Pharmacol. Exp. Ther. 340, 529-538. doi: 10.1124/jpet.111.186460

Chen, X. T., Pitis, P., Liu, G., Yuan, C., Gotchev, D., Cowan, C. L., et al. (2013). Structure-activity relationships and discovery of a $\mathrm{G}$ protein biased mu opioid receptor ligand, [(3-methoxythiophen-2-yl)methyl](\{2-[(9R)-9-(pyridin-2-yl)6-oxaspiro-[4.5] decan-9-yl] ethyl\})amine (TRV130), for the treatment of acute severe pain. J. Med. Chem. 56, 8019-8031. doi: 10.1021/jm4010829

Cherezov, V., Peddi, A., Muthusubramaniam, L., Zheng, Y. F., and Caffrey, M. (2004). A robotic system for crystallizing membrane and soluble proteins in lipidic mesophases. Acta Crystallogr. D. Biol. Crystallogr. 60, 1795-1807. doi: 10.1107/S0907444904019109

Cherezov, V., Rosenbaum, D. M., Hanson, M. A., Rasmussen, S. G., Thian, F. S., Kobilka, T. S., et al. (2007). High-resolution crystal structure of an engineered 
human beta2-adrenergic G protein-coupled receptor. Science 318, 1258-1265. doi: 10.1126/science.1150577

Chien, E. Y., Liu, W., Zhao, Q., Katritch, V., Han, G. W., Hanson, M. A., et al. (2010). Structure of the human dopamine D3 receptor in complex with a D2/D3 selective antagonist. Science 330, 1091-1095. doi: 10.1126/science.1197410

Christopher, J. A., Brown, J., Dore, A. S., Errey, J. C., Koglin, M., Marshall, F. H., et al. (2013). Biophysical fragment screening of the betal-adrenergic receptor: identification of high affinity arylpiperazine leads using structure-based drug design. J. Med. Chem. 56, 3446-3455. doi: 10.1021/jm400140q

Christopoulos, A. (2002). Allosteric binding sites on cell-surface receptors: novel targets for drug discovery. Nat. Rev. Drug Discov. 1, 198-210. doi: 10.1038/nrd746

Chun, E., Thompson, A. A., Liu, W., Roth, C. B., Griffith, M. T., Katritch, V., et al. (2012). Fusion partner toolchest for the stabilization and crystallization of $G$ protein-coupled receptors. Structure 20, 967-976. doi: 10.1016/j.str.2012.04.010

Dahan, A. (2007). Respiratory depression with opioids. J. Pain Palliat. Care Pharmacother. 21, 63-66. doi: 10.1080/J354v21n01_15

Daniels, D. J., Lenard, N. R., Etienne, C. L., Law, P. Y., Roerig, S. C., and Portoghese, P. S. (2005). Opioid-induced tolerance and dependence in mice is modulated by the distance between pharmacophores in a bivalent ligand series. Proc. Natl. Acad. Sci. U.S.A. 102, 19208-19213. doi: 10.1073/pnas.0506627102

DeWire, S. M., Ahn, S., Lefkowitz, R. J., and Shenoy, S. K. (2007) Beta-arrestins and cell signaling. Annu. Rev. Physiol. 69, 483-510. doi: 10.1146/annurev.ph.69.013107.100021

DeWire, S. M., and Violin, J. D. (2011). Biased ligands for better cardiovascular drugs: dissecting G-protein-coupled receptor pharmacology. Circ. Res. 109, 205 216. doi: 10.1161/CIRCRESAHA.110.231308

Di Marzo, V. (2008). Targeting the endocannabinoid system: to enhance or reduce? Nat. Rev. Drug Discov. 7, 438-455. doi: 10.1038/nrd2553

Dore, A. S., Okrasa, K., Patel, J. C., Serrano-Vega, M., Bennett, K., Cooke, R. M., et al. (2014). Structure of class C GPCR metabotropic glutamate receptor 5 transmembrane domain. Nature 511, 557-562. doi: 10.1038/nature13396

Dormishian, M., Turkeri, G., Urayama, K., Nguyen, T. L., Boulberdaa, M., Messaddeq, N., et al. (2013). Prokineticin receptor-1 is a new regulator of endothelial insulin uptake and capillary formation to control insulin sensitivity and cardiovascular and kidney functions. J. Am. Heart Assoc. 2, e000411. 10.1161/JAHA.113.000411

Fatkenheuer, G., Pozniak, A. L., Johnson, M. A., Plettenberg, A., Staszewski, S., Hoepelman, A. I., et al. (2005). Efficacy of short-term monotherapy with maraviroc, a new CCR5 antagonist, in patients infected with HIV-1. Nat. Med. 11, 1170-1172. doi: $10.1038 / \mathrm{nm} 1319$

Fenalti, G., Giguere, P. M., Katritch, V., Huang, X. P., Thompson, A. A., Cherezov, V., et al. (2014). Molecular control of delta-opioid receptor signaling. Nature 506, 191-196. doi: 10.1038/nature12944

Fernandez-Fuentes, N., Rai, B. K., Madrid-Aliste, C. J., Fajardo, J. E., and Fiser, A. (2007). Comparative protein structure modeling by combining multiple templates and optimizing sequence-to-structure alignments. Bioinformatics 23, 2558-2565. doi: 10.1093/bioinformatics/btm377

Funk, O. F., Kettmann, V., Drimal, J., and Langer, T. (2004). Chemical function based pharmacophore generation of endothelin-A selective receptor antagonists. J. Med. Chem. 47, 2750-2760. doi: 10.1021/jm031041j

Garner, A. R., Rowland, D. C., Hwang, S. Y., Baumgaertel, K., Roth, B. L., Kentros, C., et al. (2012). Generation of a synthetic memory trace. Science 335, 1513-1516. doi: 10.1126/science.1214985

Gemma, S., Brogi, S., Novellino, E., Campiani, G., Maga, G., Brindisi, M., et al. (2014a). HCV-targeted antivirals: current status and future challenges. Curr. Pharm. Des. 20, 3445-3464. doi: 10.2174/13816128113199990630

Gemma, S., Brogi, S., Patil, P. R., Giovani, S., Lamponi, S., Cappelli, A., et al. (2014b). From (+)-epigallocatechin gallate to a simplified synthetic analogue as a cytoadherence inhibitor for P. falciparum. RSC Adv. 4, 4769-4781. doi $10.1039 / \mathrm{c} 3 \mathrm{ra} 45933 \mathrm{k}$

Gesty-Palmer, D., Flannery, P., Yuan, L., Corsino, L., Spurney, R., Lefkowitz, R. J., et al. (2009). A beta-arrestin-biased agonist of the parathyroid hormone receptor (PTH1R) promotes bone formation independent of G protein activation. Sci. Transl. Med. 1, 1ral. doi: 10.1126/scitranslmed.3000071

Giovani, S., Penzo, M., Brogi, S., Brindisi, M., Gemma, S., Novellino, E., et al. (2014). Rational design of the first difluorostatone-based PfSUB1 inhibitors. Bioorg. Med. Chem. Lett. 24, 3582-3586. doi: 10.1016/j.bmcl.2014. 05.044
Goodfriend, T. L., Elliott, M. E., and Catt, K. J. (1996). Angiotensin receptors and their antagonists. N. Engl. J. Med. 334, 1649-1654. doi: 10.1056/NEJM199606203342507

Granier, S., Manglik, A., Kruse, A. C., Kobilka, T. S., Thian, F. S., Weis, W. I., et al. (2012). Structure of the delta-opioid receptor bound to naltrindole. Nature 485, 400-404. doi: 10.1038/nature11111

Grasberger, H., Van Sande, J., Hag-Dahood Mahameed, A., Tenenbaum-Rakover, Y., and Refetoff, S. (2007). A familial thyrotropin (TSH) receptor mutation provides in vivo evidence that the inositol phosphates/Ca2 + cascade mediates TSH action on thyroid hormone synthesis. J. Clin. Endocrinol. Metab. 92, 2816-2820. doi: 10.1210/jc.2007-0366

Guettier, J. M., Gautam, D., Scarselli, M., Ruiz De Azua, I., Li, J. H., Rosemond, E., et al. (2009). A chemical-genetic approach to study $\mathrm{G}$ protein regulation of beta cell function in vivo. Proc. Natl. Acad. Sci. U.S.A. 106, 19197-19202. doi: 10.1073/pnas.0906593106

Haga, K., Kruse, A. C., Asada, H., Yurugi-Kobayashi, T., Shiroishi, M., Zhang, C., et al. (2012). Structure of the human M2 muscarinic acetylcholine receptor bound to an antagonist. Nature 482, 547-551. doi: 10.1038/nature10753

Hanson, M. A., Cherezov, V., Griffith, M. T., Roth, C. B., Jaakola, V. P., Chien, E. Y., et al. (2008). A specific cholesterol binding site is established by the $2.8 \mathrm{~A}$ structure of the human beta2-adrenergic receptor. Structure 16, 897-905. doi: 10.1016/j.str.2008.05.001

Hanson, M. A., Roth, C. B., Jo, E., Griffith, M. T., Scott, F. L., Reinhart, G., et al. (2012). Crystal structure of a lipid G protein-coupled receptor. Science 335, 851855. doi: 10.1126/science. 1215904

Hollenstein, K., Kean, J., Bortolato, A., Cheng, R. K., Dore, A. S., Jazayeri, A., et al. (2013). Structure of class B GPCR corticotropin-releasing factor receptor 1. Nature 499, 438-443. doi: 10.1038/nature12357

Jaakola, V. P., Griffith, M. T., Hanson, M. A., Cherezov, V., Chien, E. Y., Lane, J. R., etal. (2008). The 2.6 angstrom crystal structure of a human A2A adenosine receptor bound to an antagonist. Science 322, 1211-1217. doi: $10.1126 /$ science. 1164772

Khoury, E., Clement, S., and Laporte, S. A. (2014). Allosteric and biased g proteincoupled receptor signaling regulation: potentials for new therapeutics. Front. Endocrinol. 5:68. doi: 10.3389/fendo.2014.00068

Kolb, P., Rosenbaum, D. M., Irwin, J. J., Fung, J. J., Kobilka, B. K., and Shoichet, B. K. (2009). Structure-based discovery of beta2-adrenergic receptor ligands. Proc. Natl. Acad. Sci. U.S.A. 106, 6843-6848. doi: 10.1073/pnas.0812657106

Kong, D., Tong, Q., Ye, C., Koda, S., Fuller, P. M., Krashes, M. J., et al. (2012). GABAergic RIP-Cre neurons in the arcuate nucleus selectively regulate energy expenditure. Cell 151, 645-657. doi: 10.1016/j.cell.2012.09.020

Kooistra, A. J., Roumen, L., Leurs, R., De Esch, I. J., and De Graaf, C. (2013). From heptahelical bundle to hits from the Haystack: structure-based virtual screening for GPCR ligands. Methods Enzymol. 522, 279-336. doi: 10.1016/B978-0-12407865-9.00015-7

Kopecky, S. L. (2006). Effect of beta blockers, particularly carvedilol, on reducing the risk of events after acute myocardial infarction. Am. J. Cardiol. 98, 1115-1119. doi: 10.1016/j.amjcard.2006.05.039

Kruse, A. C., Hu, J., Pan, A. C., Arlow, D. H., Rosenbaum, D. M., Rosemond, E., et al. (2012). Structure and dynamics of the M3 muscarinic acetylcholine receptor. Nature 482, 552-556. doi: 10.1038/nature10867

Kruse, A. C., Weiss, D. R., Rossi, M., Hu, J., Hu, K., Eitel, K., et al. (2013). Muscarinic receptors as model targets and antitargets for structure-based ligand discovery. Mol. Pharmacol. 84, 528-540. doi: 10.1124/mol.113.087551

Lane, J. R., Chubukov, P., Liu, W., Canals, M., Cherezov, V., Abagyan, R., et al. (2013). Structure-based ligand discovery targeting orthosteric and allosteric pockets of dopamine receptors. Mol. Pharmacol. 84, 794-807. doi: 10.1124/mol.113. 088054

Leach, K., Wen, A., Davey, A. E., Sexton, P. M., Conigrave, A. D., and Christopoulos, A. (2012). Identification of molecular phenotypes and biased signaling induced by naturally occurring mutations of the human calcium-sensing receptor. Endocrinology 153, 4304-4316. doi: 10.1210/en.2012-1449

Lefkowitz, R. J., and Shenoy, S. K. (2005). Transduction of receptor signals by beta-arrestins. Science 308, 512-517. doi: 10.1126/science.1109237

Li, Y. Y., Hou, T. J., and Goddard, W. A. III. (2010). Computational modeling of structure-function of $\mathrm{g}$ protein-coupled receptors with applications for drug design. Curr. Med. Chem. 17, 1167-1180. doi: 10.2174/092986710790 827807 
Luttrell, L. M., Ferguson, S. S., Daaka, Y., Miller, W. E., Maudsley, S., Della Rocca, G. J., et al. (1999). Beta-arrestin-dependent formation of beta2 adrenergic receptor-Src protein kinase complexes. Science 283, 655-661. doi: $10.1126 /$ science. 283.5402 .655

Mailman, R. B., and Murthy, V. (2010). Third generation antipsychotic drugs: partial agonism or receptor functional selectivity? Curr. Pharm. Des. 16, 488-501. doi: $10.2174 / 138161210790361461$

Manglik, A., Kruse, A. C., Kobilka, T. S., Thian, F. S., Mathiesen, J. M., Sunahara, R. K., et al. (2012). Crystal structure of the micro-opioid receptor bound to a morphinan antagonist. Nature 485, 321-326. doi: 10.1038/nature10954

Masri, B., Salahpour, A., Didriksen, M., Ghisi, V., Beaulieu, J. M., Gainetdinov, R. R., et al. (2008). Antagonism of dopamine D2 receptor/beta-arrestin 2 interaction is a common property of clinically effective antipsychotics. Proc. Natl. Acad. Sci. U.S.A. 105, 13656-13661. doi: 10.1073/pnas.0803522105

Matsuda, L. A., Lolait, S. J., Brownstein, M. J., Young, A. C., and Bonner, T. I. (1990). Structure of a cannabinoid receptor and functional expression of the cloned cDNA. Nature 346, 561-564. doi: 10.1038/346561a0

Meng, T., Wang, J., Peng, H., Fang, G., Li, M., Xiong, B., et al. (2010). Discovery of benzhydrylpiperazine derivatives as $\mathrm{CB} 1$ receptor inverse agonists via privileged structure-based approach. Eur. J. Med. Chem. 45, 1133-1139. doi: 10.1016/j.ejmech.2009.12.018

Mobarec, J. C., Sanchez, R., and Filizola, M. (2009). Modern homology modeling of G-protein coupled receptors: which structural template to use? J. Med. Chem. 52, 5207-5216. doi: 10.1021/jm9005252

Mohr, K., Schmitz, J., Schrage, R., TrãNkle, C., and Holzgrabe, U. (2013). Molecular alliance - from orthosteric and allosteric ligands to dualsteric/bitopic agonists at G protein coupled receptors. Angew. Chem. Int. Ed. Engl. 52, 508-516.

Monasky, M. M., Taglieri, D. M., Henze, M., Warren, C. M., Utter, M. S., Soergel, D. G., et al. (2013). The beta-arrestin-biased ligand TRV120023 inhibits angiotensin II-induced cardiac hypertrophy while preserving enhanced myofilament response to calcium. Am. J. Physiol. Heart Circ. Physiol. 305, H856-H866. doi: 10.1152/ajpheart.00327.2013

Nebigil, C. G. (2009). Prokineticin receptors in cardiovascular function: foe or friend? Trends Cardiovasc. Med. 19, 55-60. doi: 10.1016/j.tcm.2009. 04.007

Negri, A., Rives, M. L., Caspers, M. J., Prisinzano, T. E., Javitch, J. A., and Filizola, M. (2013). Discovery of a novel selective kappa-opioid receptor agonist using crystal structure-based virtual screening. J. Chem. Inf. Model. 53, 521-526. doi: $10.1021 / \mathrm{ci} 400019 \mathrm{t}$

Nygaard, R., Zou, Y., Dror, R. O., Mildorf, T. J., Arlow, D. H., Manglik, A., et al. (2013). The dynamic process of beta(2)-adrenergic receptor activation. Cell 152, 532-542. doi: 10.1016/j.cell.2013.01

Oliveira, L., Costa-Neto, C. M., Nakaie, C. R., Schreier, S., Shimuta, S. I., and Paiva, A. C. (2007). The angiotensin II AT1 receptor structure-activity correlations in the light of rhodopsin structure. Physiol. Rev. 87, 565-592. doi: 10.1152/physrev.00040.2005

Pal, M., and Paliwal, S. (2012). In silico identification of novel lead compounds with AT1 receptor antagonist activity: successful application of chemical database screening protocol. Org. Med. Chem. Lett. 2, 7. doi: 10.1186/21912858-2-7

Palczewski, K., Kumasaka, T., Hori, T., Behnke, C. A., Motoshima, H., Fox, B. A., et al. (2000). Crystal structure of rhodopsin: a G protein-coupled receptor. Science 289, 739-745. doi: 10.1126/science.289.5480.739

Pandey, P., Roy, K. K., Liu, H., Elokely, K. M., Pettaway, S., Cutler, S. J., et al. (2014). Search for cannabinoid receptor 1 antagonists using structure-based virtual screening: identification of natural product hits. Planta Med. 80, PF11. doi: 10.1055/s-0034-1382589

Park, J. H., Scheerer, P., Hofmann, K. P., Choe, H. W., and Ernst, O. P. (2008). Crystal structure of the ligand-free G-protein-coupled receptor opsin. Nature 454, 183-187. doi: 10.1038/nature07063

Park, S. H., Das, B. B., Casagrande, F., Tian, Y., Nothnagel, H. J., Chu, M., et al. (2012). Structure of the chemokine receptor CXCR1 in phospholipid bilayers. Nature 491, 779-783. doi: 10.1038/nature11580

Pasquini, S., Mugnaini, C., Ligresti, A., Tafi, A., Brogi, S., Falciani, C., et al. (2012). Design, synthesis, and pharmacological characterization of indol-3ylacetamides, indol-3-yloxoacetamides, and indol-3-ylcarboxamides: potent and selective CB2 cannabinoid receptor inverse agonists. J. Med. Chem. 55, 5391-5402. doi: $10.1021 / \mathrm{jm} 3003334$
Percherancier, Y., Berchiche, Y. A., Slight, I., Volkmer-Engert, R., Tamamura, H., Fujii, N., et al. (2005). Bioluminescence resonance energy transfer reveals ligandinduced conformational changes in CXCR4 homo- and heterodimers. J. Biol. Chem. 280, 9895-9903. doi: 10.1074/jbc.M411151200

Perez, M., Pauwels, P. J., Fourrier, C., Chopin, P., Valentin, J. P., John, G. W., et al. (1998). Dimerization of sumatriptan as an efficient way to design a potent, centrally and orally active 5-HT1B agonist. Bioorg. Med. Chem. Lett. 8, 675-680. doi: 10.1016/S0960-894X(98)00090-0

Pivonello, R., Ferone, D., Lombardi, G., Colao, A., Lamberts, S. W., and Hofland, L. J. (2007). Novel insights in dopamine receptor physiology. Eur. J. Endocrinol. 156(Suppl. 1), S13-S21. doi: 10.1530/eje.1.02353

Pollock, D. M., Keith, T. L., and Highsmith, R. F. (1995). Endothelin receptors and calcium signaling. FASEB J. 9, 1196-1204.

Poole-Wilson, P. A., Swedberg, K., Cleland, J. G., Di Lenarda, A., Hanrath, P., Komajda, M., et al. (2003). Comparison of carvedilol and metoprolol on clinical outcomes in patients with chronic heart failure in the carvedilol or metoprolol european trial (COMET): randomised controlled trial. Lancet 362, 7-13. doi: 10.1016/S0140-6736(03)13800-7

Rajagopal, S., Rajagopal, K., and Lefkowitz, R. J. (2010). Teaching old receptors new tricks: biasing seven-transmembrane receptors. Nat. Rev. Drug Discov. 9, 373-386. doi: 10.1038/nrd3024

Rashid, A. J., O'dowd, B. F., Verma, V., and George, S. R. (2007). Neuronal Gq/11coupled dopamine receptors: an uncharted role for dopamine. Trends Pharmacol. Sci. 28, 551-555. doi: 10.1016/j.tips.2007.10.001

Rasmussen, S. G., Choi, H. J., Rosenbaum, D. M., Kobilka, T. S., Thian, F. S., Edwards, P. C., et al. (2007). Crystal structure of the human beta2 adrenergic G-protein-coupled receptor. Nature 450, 383-387. doi: 10.1038/nature06325

Renault, N., Laurent, X., Farce, A., El Bakali, J., Mansouri, R., Gervois, P., et al. (2013). Virtual screening of $\mathrm{CB}(2)$ receptor agonists from bayesian network and high-throughput docking: structural insights into agonist-modulated GPCR features. Chem. Biol. Drug Des. 81, 442-454. doi: 10.1111/cbdd.12095

Rominger, D. H., Cowan, C. L., Gowen-Macdonald, W., and Violin, J. D. (2014). Biased ligands: pathway validation for novel GPCR therapeutics. Curr. Opin. Pharmacol. 16, 108-115. doi: 10.1016/j.coph.2014.04.002

Rosenbaum, D. M., Cherezov, V., Hanson, M. A., Rasmussen, S. G., Thian, F. S., Kobilka, T. S., et al. (2007). GPCR engineering yields high-resolution structural insights into beta2-adrenergic receptor function. Science 318, 1266-1273. doi: 10.1126/science.1150609

Sabio, M., Jones, K., and Topiol, S. (2008). Use of the X-ray structure of the beta2adrenergic receptor for drug discovery. Part 2: identification of active compounds. Bioorg. Med. Chem. Lett. 18, 5391-5395. doi: 10.1016/j.bmcl.2008.09.046

Saito, Y., and Berk, B. C. (2001). Transactivation: a novel signaling pathway from angiotensin II to tyrosine kinase receptors. J. Mol. Cell Cardiol. 33, 3-7. doi: $10.1006 /$ jmcc. 2000

Sbai, O., Monnier, C., Dode, C., Pin, J. P., Hardelin, J. P., and Rondard, P. (2014). Biased signaling through G-protein-coupled PROKR2 receptors harboring missense mutations. FASEB J. 28, 3734-3744. doi: 10.1096/fj.13-243402

Scherrer, G., Imamachi, N., Cao, Y. Q., Contet, C., Mennicken, F., O'donnell, D., et al. (2009). Dissociation of the opioid receptor mechanisms that control mechanical and heat pain. Cell 137, 1148-1159. doi: 10.1016/j.cell.2009.04.019

Scheerer, P., Park, J. H., Hildebrand, P. W., Kim, Y. J., Krauss, N., Choe, H. W., et al. (2008). Crystal structure of opsin in its G-protein-interacting conformation. Nature 455, 497-502. doi: 10.1038/nature07330

Scholten, D. J., Canals, M., Maussang, D., Roumen, L., Smit, M. J., Wijtmans, M., et al. (2012). Pharmacological modulation of chemokine receptor function. Br. J. Pharmacol. 165, 1617-1643. doi: 10.1111/j.1476-5381.2011. 01551.x

Serrano-Vega, M. J., Magnani, F., Shibata, Y., and Tate, C. G. (2008). Conformational thermostabilization of the betal-adrenergic receptor in a detergent-resistant form. Proc. Natl. Acad. Sci. U.S.A. 105, 877-882. doi: 10.1073/pnas.0711 253105

Shapiro, D. A., Renock, S., Arrington, E., Chiodo, L. A., Liu, L. X., Sibley, D. R., et al. (2003). Aripiprazole, a novel atypical antipsychotic drug with a unique and robust pharmacology. Neuropsychopharmacology 28, 1400-1411. doi: 10.1038/sj.npp.1300203

Shimamura, T., Shiroishi, M., Weyand, S., Tsujimoto, H., Winter, G., Katritch, V., et al. (2011). Structure of the human histamine H1 receptor complex with doxepin. Nature 475, 65-70. doi: 10.1038/nature10236 
Sigalov, A. B. (2012). "Monovalen" ligands that trigger TLR-4 and TCR are not necessarily truly monovalent. Mol. Immunol. 51, 356-362. doi: 10.1016/j.molimm.2012.03.031

Sinisi, A. A., Asci, R., Bellastella, G., Maione, L., Esposito, D., Elefante, A., et al. (2008). Homozygous mutation in the prokineticin-receptor2 gene (Val274Asp) presenting as reversible Kallmann syndrome and persistent oligozoospermia: case report. Hum. Reprod. 23, 2380-2384. doi: 10.1093/humrep/den247

Siu, F. Y., He, M., De Graaf, C., Han, G. W., Yang, D., Zhang, Z., et al. (2013). Structure of the human glucagon class B G-protein-coupled receptor. Nature 499, 444-449. doi: 10.1038/nature12393

Soergel, D. G., Subach, R. A., Sadler, B., Connell, J., Marion, A. S., Cowan, C. L., et al. (2014). First clinical experience with TRV130: pharmacokinetics and pharmacodynamics in healthy volunteers. J. Clin. Pharmacol. 54, 351-357. doi: 10.1002/jcph.207

Sokkar, P., Mohandass, S., and Ramachandran, M. (2011). Multiple templatesbased homology modeling enhances structure quality of AT1 receptor: validation by molecular dynamics and antagonist docking. J. Mol. Model. 17, 1565-1577. doi: 10.1007/s00894-010-0860-z

Szatkowski, C., Vallet, J., Dormishian, M., Messaddeq, N., Valet, P., Boulberdaa M., et al. (2013). Prokineticin receptor 1 as a novel suppressor of preadipocyte proliferation and differentiation to control obesity. PLOS ONE 8:e81175. doi: 10.1371/journal.pone.0081175

Tan, Q., Zhu, Y., Li, J., Chen, Z., Han, G. W., Kufareva, I., et al. (2013). Structure of the CCR5 chemokine IV entry inhibitor maraviroc complex. Science 341, 1387-1390. doi: $10.1126 /$ science. 1241475

Thompson, A. A., Liu, W., Chun, E., Katritch, V., Wu, H., Vardy, E., et al. (2012). Structure of the nociceptin/orphanin FQ receptor in complex with a peptide mimetic. Nature 485, 395-399. doi: 10.1038/nature11085

Topiol, S., and Sabio, M. (2008). Use of the X-ray structure of the Beta2-adrenergic receptor for drug discovery. Bioorg. Med. Chem. Lett. 18, 1598-1602. doi: 10.1016/j.bmcl.2008.01.063

Torres, P. U. (2006). Cinacalcet HCl: a novel treatment for secondary hyperparathyroidism caused by chronic kidney disease. J. Ren. Nutr. 16, 253-258. doi: 10.1053/j.jrn.2006.04.010

Urban, J. D., Vargas, G. A., Von Zastrow, M., and Mailman, R. B. (2007). Aripiprazole has functionally selective actions at dopamine D2 receptor-mediated signaling pathways. Neuropsychopharmacology 32, 67-77. doi: 10.1038/sj.npp.13 01071

Valant, C., May, L. T., Aurelio, L., Chuo, C. H., White, P. J., Baltos, J. A., et al. (2014). Separation of on-target efficacy from adverse effects through rational design of a bitopic adenosine receptor agonist. Proc. Natl. Acad. Sci. U.S.A. 111, 4614-4619. doi: $10.1073 /$ pnas.1320962111

Vallone, D., Picetti, R., and Borrelli, E. (2000). Structure and function of dopamine receptors. Neurosci. Biobehav. Rev. 24, 125-132. doi: 10.1016/S01497634(99)00063-9

Vass, M., Schmidt, E., Horti, F., and Keseru, G. M. (2014). Virtual fragment screening on GPCRs: a case study on dopamine D3 and histamine H4 receptors. Eur. J. Med. Chem. 77, 38-46. doi: 10.1016/j.ejmech.2014.02.034

Vilar, S., Karpiak, J., and Costanzi, S. (2010). Ligand and structure-based models for the prediction of ligand-receptor affinities and virtual screenings: development and application to the beta(2)-adrenergic receptor. J. Comput. Chem. 31, 707-720. doi: $10.1002 /$ jcc. 21346

Violin, J. D., Crombie, A. L., Soergel, D. G., and Lark, M. W. (2014). Biased ligands at G-protein-coupled receptors: promise and progress. Trends Pharmacol. Sci. 35, 308-316. doi: 10.1016/j.tips.2014.04.007

Violin, J. D., and Lefkowitz, R. J. (2007). Beta-arrestin-biased ligands at seven-transmembrane receptors. Trends Pharmacol. Sci. 28, 416-422. doi: 10.1016/j.tips.2007.06.006

Wacker, D., Wang, C., Katritch, V., Han, G. W., Huang, X. P., Vardy, E., et al. (2013). Structural features for functional selectivity at serotonin receptors. Science 340, 615-619. doi: 10.1126/science. 1232808

Waldhoer, M., Fong, J., Jones, R. M., Lunzer, M. M., Sharma, S. K., Kostenis, E., et al. (2005). A heterodimer-selective agonist shows in vivo relevance of $\mathrm{G}$ protein-coupled receptor dimers. Proc. Natl. Acad. Sci. U.S.A. 102, 9050-9055. doi: 10.1073/pnas.0501112102

Wang, C., Jiang, Y., Ma, J., Wu, H., Wacker, D., Katritch, V., et al. (2013a). Structural basis for molecular recognition at serotonin receptors. Science 340, 610-614. doi: $10.1126 /$ science. 1232807
Wang, C., Wu, H., Katritch, V., Han, G. W., Huang, X. P., Liu, W., et al. (2013b) Structure of the human smoothened receptor bound to an antitumour agent. Nature 497, 338-343. doi: 10.1038/nature12167

Wang, H., Duffy, R. A., Boykow, G. C., Chackalamannil, S., and Madison, V. S. (2008). Identification of novel cannabinoid CB1 receptor antagonists by using virtual screening with a pharmacophore model. J. Med. Chem. 51, 2439-2446. doi: 10.1021/jm701519h

Warne, T., Serrano-Vega, M. J., Baker, J. G., Moukhametzianov, R., Edwards, P. C., Henderson, R., et al. (2008). Structure of a betal-adrenergic G-protein-coupled receptor. Nature 454, 486-491. doi: 10.1038/nature07101

Wei, H., Ahn, S., Shenoy, S. K., Karnik, S. S., Hunyady, L., Luttrell, L. M., et al. (2003). Independent beta-arrestin 2 and $\mathrm{G}$ protein-mediated pathways for angiotensin II activation of extracellular signal-regulated kinases 1 and 2. Proc. Natl. Acad. Sci. U.S.A. 100, 10782-10787. doi: 10.1073/pnas.1834556100

Weiss, D. R., Ahn, S., Sassano, M. F., Kleist, A., Zhu, X., Strachan, R., et al. (2013) Conformation guides molecular efficacy in docking screens of activated beta2 adrenergic G protein coupled receptor. ACS Chem. Biol. 8, 1018-1026. doi: $10.1021 / \mathrm{cb} 400103 \mathrm{f}$

Whalen, E. J., Rajagopal, S., and Lefkowitz, R. J. (2011). Therapeutic potential of beta-arrestin- and G protein-biased agonists. Trends Mol. Med. 17, 126-139. doi: 10.1016/j.molmed.2010.11.004

White, J. F., Noinaj, N., Shibata, Y., Love, J., Kloss, B., Xu, F., et al. (2012). Structure of the agonist-bound neurotensin receptor. Nature 490, 508-513. doi: $10.1038 /$ nature 11558

Williams, R., Zhou, Y., Niswender, C. M., Luo, Q., Conn, P. J., Lindsley, C. W., et al. (2010). Re-exploration of the PHCCC Scaffold: discovery of improved positive allosteric modulators of mGluR4. ACS Chem. Neurosci. 1, 411-419. doi: $10.1021 / \mathrm{cn} 9000318$

Wu, B., Chien, E. Y., Mol, C. D., Fenalti, G., Liu, W., Katritch, V., et al. (2010). Structures of the CXCR4 chemokine GPCR with small-molecule and cyclic peptide antagonists. Science 330, 1066-1071. doi: 10.1126/science.1194396

Wu, H., Wacker, D., Mileni, M., Katritch, V., Han, G. W., Vardy, E., et al. (2012). Structure of the human kappa-opioid receptor in complex with JDTic. Nature 485, 327-332. doi: 10.1038/nature10939

Xing, R. J., Wang, J., Pan, L., and Cheng, M. S. (2009). A selective pharmacophore model for beta(2)-adrenoceptor agonists. Molecules 14, 4486-4496. doi: 10.3390/molecules14114486

Yekkirala, A. S., Lunzer, M. M., Mccurdy, C. R., Powers, M. D., Kalyuzhny, A. E., Roerig, S. C., et al. (2011). N-naphthoyl-beta-naltrexamine (NNTA), a highly selective and potent activator of mu/kappa-opioid heteromers. Proc. Natl. Acad. Sci. U.S.A. 108, 5098-5103. doi: 10.1073/pnas.1016277108

Zhang, C., Srinivasan, Y., Arlow, D. H., Fung, J. J., Palmer, D., Zheng, Y., et al. (2012). High-resolution crystal structure of human protease-activated receptor 1. Nature 492, 387-392. doi: 10.1038/nature11701

Zhang, J., Zhang, K., Gao, Z. G., Paoletta, S., Zhang, D., Han, G. W., et al. (2014). Agonist-bound structure of the human P2Y12 receptor. Nature 509, 119-122. doi: $10.1038 /$ nature 13288

Zhang, Y., Gilliam, A., Maitra, R., Damaj, M. I., Tajuba, J. M., Seltzman, H. H., et al. (2010). Synthesis and biological evaluation of bivalent ligands for the cannabinoid 1 receptor. J. Med. Chem. 53, 7048-7060. doi: 10.1021/jm1006676

Conflict of Interest Statement: The authors declare that the research was conducted in the absence of any commercial or financial relationships that could be construed as a potential conflict of interest.

Received: 22 September 2014; accepted: 02 November 2014; published online: 28 November 2014.

Citation: Brogi S, Tafi A, Désaubry L and Nebigil CG (2014) Discovery of GPCR ligands for probing signal transduction pathways. Front. Pharmacol. 5:255. doi: 10.3389/fphar.2014.00255

This article was submitted to Neuropharmacology, a section of the journal Frontiers in Pharmacology.

Copyright (C) 2014 Brogi, Tafi, Désaubry and Nebigil. This is an open-access article distributed under the terms of the Creative Commons Attribution License(CC BY). The use, distribution or reproduction in other forums is permitted, provided the original author(s) or licensor are credited and that the original publication in this journal is cited, in accordance with accepted academic practice. No use, distribution or reproduction is permitted which does not comply with these terms. 